\title{
St. Kitts and Nevis-Third Review Under the Stand-By Arrangement, Financing Assurances Review and Request for Waivers of Applicability_Staff Report and Press Release on the Executive Board Discussion
}

The following documents have been released and are included in this package:

- $\quad$ The staff report for the third review under the Stand-By Arrangement, financing assurances review and request for waivers of applicability, prepared by a staff team of the IMF, following discussions that ended on June 15, 2012 with the officials of St. Kitts and Nevis on economic developments and policies. Based on information available at the time of these discussions, the staff report was completed on July 18, 2012. The views expressed in the staff report are those of the staff team and do not necessarily reflect the views of the Executive Board of the IMF.

- A press release on the Executive Board discussion.

The policy of publication of staff reports and other documents allows for the deletion of market-sensitive information.

Copies of this report are available to the public from

International Monetary Fund • Publication Services

$70019^{\text {th }}$ Street, N.W. • Washington, D.C. 20431

Telephone: (202) 623-7430 • Telefax: (202) 623-7201

E-mail: publications@imf.org Internet: http://www.imf.org

\section{International Monetary Fund Washington, D.C.}




\title{
INTERNATIONAL MONETARY FUND
}

\author{
ST. KITTS AND NEVIS
}

\section{Third Review under the Stand-By Arrangement, Financing Assurances Review and Request for Waivers of Applicability}

Prepared by the Western Hemisphere Department
(In Consultation with Other Departments)

Approved by David Vegara and Thomas Dorsey

July 18,2012

\section{Executive Summary}

Context. Economic activity is estimated to have softened below program expectations in January-March 2012, due to a continued contraction in the construction sector which dominated a relatively strong outturn in tourism. Despite this growth underperformance and the continued global uncertainty, the authorities have successfully implemented their home-grown economic program. While the outlook is for a moderate economic recovery, uncertain external conditions continue to present downside risks to growth.

Stand-By Arrangement (SBA). On July 27, 2011, the Executive Board approved a 36-month SBA for St. Kitts and Nevis for SDR 52.51 million (590 percent of quota) to support the authorities' program (Country Report No. 11/270). A tranche of SDR 3.161 million will be made available upon completion of this review.

Program Performance. All quantitative performance criteria (PC) for end-March 2012 were met, as were the structural benchmarks at end-March and end-June 2012. The authorities have made further progress in a comprehensive debt restructuring, including the conclusion of an agreement with their Paris Club creditors on May 24, 2012. The authorities requested waivers of applicability for the quantitative PC for end-June 2012.

Review. In the attached supplementary Letter of Intent and Memorandum of Economic and Financial Policies, the authorities elaborate on their policies for the remainder of 2012, which are in line with the program, and propose corresponding quantitative performance criteria. Staff supports the authorities' request for the completion of the third program review and the financing assurances review under the SBA.

Mission. The staff team comprised G. Tsibouris (Head), Ms. D. Simard, Mr. K. Greenidge, Ms. S. Ogawa (all WHD), and Mr. Moriyama (SPR); it was assisted by Mr. W. Samuel (Regional Resident Representative). During June 4-18, 2012, the mission met with the Prime Minister and Finance Minister of St. Kitts and Nevis, the Premier of Nevis, the Cabinet, the ECCB Governor and senior staff, as well as other senior Government officials and representatives of the private sector. Mr. M. Sajkunovic (OED) attended the final meetings. 
Executive Summary

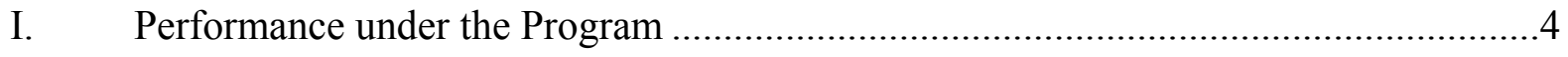

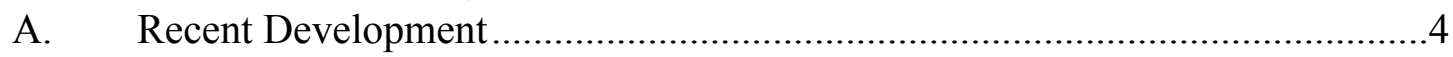

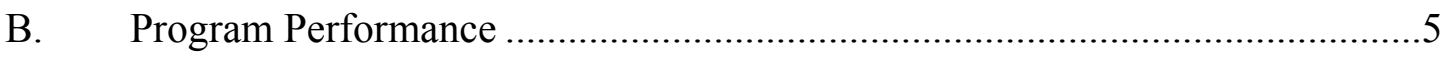

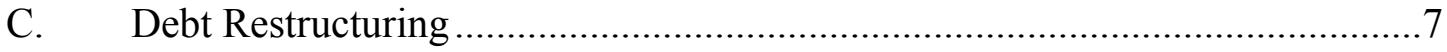

II. Policy Discussions ........................................................................................

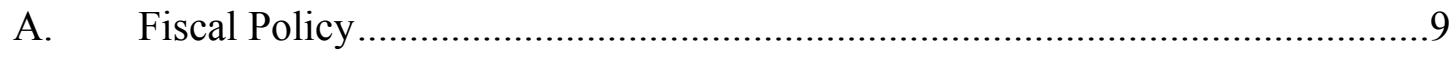

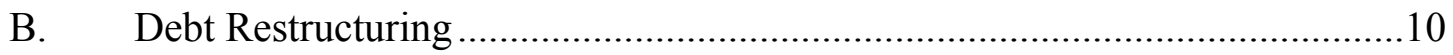

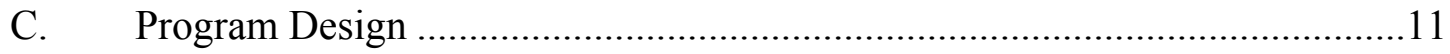

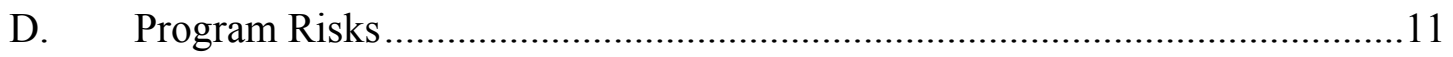

III. Staff Appraisal ............................................................................................ 11

Box

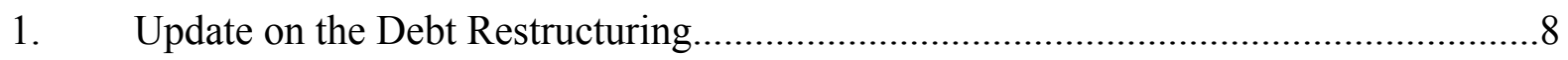

Figures

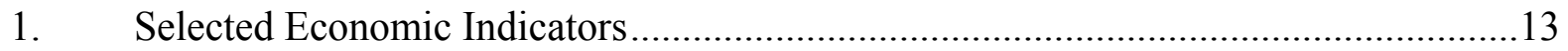

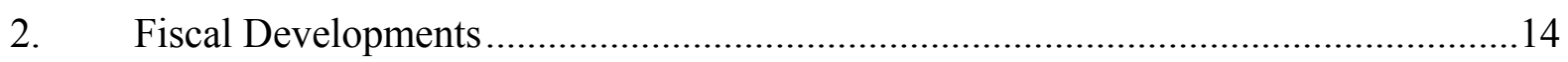

3. Developments in the Local Banking System, 2010-12 .......................................15

4. External Debt Sustainability: Bound Tests .........................................................16

5. Public Debt Sustainability: Bound Tests ...........................................................17

Tables

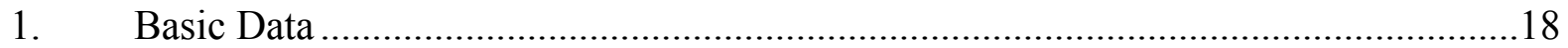

2. Central Government Fiscal Operations, 2008-17.................................................. 19

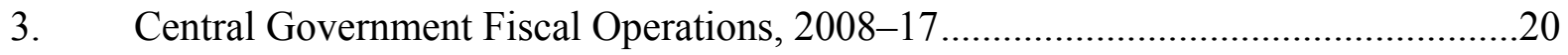

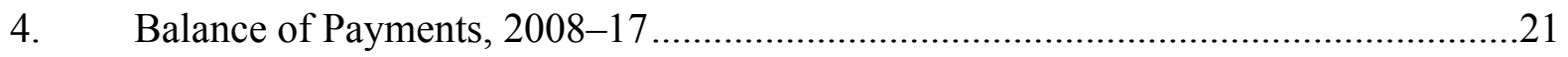

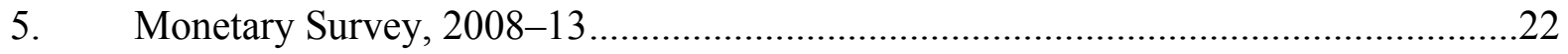

6. Indicators of External and Financial Vulnerability, 2006-11 ................................23

7. External Financing Requirement and Sources, 2011-17 .......................................24

8. Indicators of Capacity to Repay the Fund, 2012-21 .............................................25

9. External Debt Sustainability Framework, 2007-17 .............................................26

10. Public Sector Debt Sustainability Framework, 2007-17 ........................................27 


\section{Appendix}

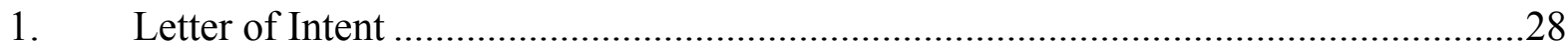

Attachment I. Memorandum of Economic and Financial Policies ..................30

Attachment II. Technical Memorandum of Understanding ...........................38 


\section{Performance Under the Program}

\section{A. Recent Developments}

1. A slump in construction has constrained economic activity below program expectations for January-March 2012, the external position strengthened, while the financial sector remained relatively sound.

- Economic activity is estimated to have softened in the first quarter of 2012, due to a continued contraction in the construction sector which dominated a relatively strong outturn in tourism. Available indicators point to a contraction of construction, by an estimated 20 to 25 percent (y/y), on account of an under-execution of public investment and sluggish FDI inflows. However, the outturn in tourism was relatively strong, with a 5 percent increase in stay-over arrivals relative to 2011. Inflation declined from 2.9 percent at end-December 2011 to 1.9 percent (y/y) at end-March 2012, with a fading impact of the introduction of the VAT at end-2010 and moderating commodity prices. ${ }^{1}$

- The external position has strengthened due to sluggish imports combined with solid exports and tourism receipts. Imports contracted relative to program expectations, reflecting lower domestic demand, while export and tourism receipts were relatively strong. The trade balance improved sufficiently to raise international reserves, net of IMF SBA resources, from US\$161 million to US\$170 million. In terms of trade policy, the Partial Scope Agreement with Brazil and Guyana, covering the electronics sector, was concluded in May 2012 and is scheduled for ratification by end-2012.

- $\quad$ The domestic financial sector has remained reasonably healthy and adequately capitalized but the loan portfolio performance and capital buffers have softened.

Liquidity coverage of total deposits increased and the capital to risk-weighted asset ratio was maintained above 40 percent, exceeding the regulatory requirements. The reported ratio of nonperforming loans (NPLs) of indigenous banks has inched up slightly in recent months and above the regional benchmark of 5 percent. Updated stress tests as of March 2012 confirm that the domestic banking sector is resilient to a range of shocks and would weather the impact of the government debt restructuring. A preliminary assessment of the impact of the debt/land swap is that the capital adequacy would remain above the regulatory requirement while the NPL ratio would increase due to the change in asset composition. ${ }^{2}$ There has been no request to date to access the Banking Sector Reserve Fund (BSRF) set up under the SBA.

\footnotetext{
${ }^{1}$ Methodological improvements in the treatment of missing data in the CPI survey have resulted in an updated historical inflation time series.

${ }^{2}$ The swap of loans for land will lead to a one-off step change in the NPL ratio by reducing the denominator by the amount of swapped loans given the dominance of the public sector in the current loan book.
} 
St. Kitts and Nevis: Selected Financial Indicators, December 2009-March 2012

\begin{tabular}{|c|c|c|c|c|c|c|c|}
\hline & Dec-09 & Dec-10 & Mar-11 & Jun-11 & Sep-11 & Dec-11 & Mar-12 \\
\hline & \multicolumn{7}{|c|}{ (Annual percentage change) } \\
\hline Broad money & 5.9 & 8.9 & 3.3 & 5.6 & 3.8 & 11.2 & 9.5 \\
\hline Private sector deposits & 4.4 & 7.9 & 2.9 & 5.7 & 3.7 & 10.5 & 9.1 \\
\hline Private sector credit & 5.5 & 3.5 & 5.8 & 3.8 & 5.6 & 3.7 & 4.7 \\
\hline \multicolumn{8}{|c|}{ (Percentage change relative to broad money at beginning of period) } \\
\hline Net foreign assets & -8.4 & 1.1 & -1.0 & 7.6 & 11.4 & 16.7 & 14.1 \\
\hline $\begin{array}{l}\text { Net domestic assets } \\
\text { of which: }\end{array}$ & 14.3 & 7.8 & 4.2 & -2.2 & -7.6 & -5.5 & -4.6 \\
\hline Private sector credit & 4.1 & 2.6 & 3.9 & 2.7 & 3.9 & 2.6 & 3.4 \\
\hline Net credit to public sector & 1.5 & 4.9 & 0.9 & -7.3 & -13.5 & -9.0 & -10.8 \\
\hline & \multicolumn{7}{|c|}{ (Indigenous banks; In percent) } \\
\hline Capital adequacy ratio & 49.3 & 43.9 & 46.3 & 48.5 & 41.6 & 42.2 & 41.9 \\
\hline NPLs/Total loans & 4.1 & 5.3 & 5.6 & 5.6 & 5.5 & 5.8 & 5.9 \\
\hline Provisioning/NPLs & 77.7 & 58.1 & 55.8 & 55.5 & 55.2 & 53.0 & 52.1 \\
\hline Net liquid asset/Total deposit & 55.4 & 50.4 & 52.3 & 52.5 & 52.6 & 52.6 & 54.3 \\
\hline Return on Equity $1 /$ & 11.3 & 4.6 & 4.3 & 9.0 & 10.2 & 14.1 & 13.9 \\
\hline Return on Asset 1/ & 2.4 & 0.9 & 0.9 & 1.8 & 2.0 & 2.7 & 2.6 \\
\hline Net operating income 1/ 2/ & 5.8 & 4.6 & 4.6 & 5.5 & 5.7 & 6.4 & 6.3 \\
\hline
\end{tabular}

\section{B. Program Performance}

\section{Despite the continued challenging global environment and the sluggish economic} activity, the authorities met all of the fiscal program targets for end-March 2012. In addition, based on preliminary data available for end-April, the authorities appear on track to meet the end-June 2012 PCs. The overall fiscal balance at end-March 2012 reached a surplus of EC\$20 million, significantly above the adjusted program floor of EC\$-24 million. Similarly, the primary surplus of EC\$46 million also exceeded the program's indicative floor of EC\$7 million. Most gains came from a sharp tightening in expenditure, notably capital outlays, with particularly sharp curtailment in public investment by the Nevis

\begin{tabular}{|c|c|c|c|}
\hline & \multicolumn{2}{|c|}{2012 Q1 } & \multirow{2}{*}{$\begin{array}{l}2012 \\
\text { Prog. }\end{array}$} \\
\hline & Prog. & Actual & \\
\hline Total revenue & 125.2 & 127.5 & 524.1 \\
\hline Tax revenue & 98.7 & 95.7 & 420.1 \\
\hline Taxes on income & 15.9 & 20.8 & 81.5 \\
\hline Taxes on property & 2.0 & 2.5 & 10.6 \\
\hline Taxes on domestic goods and consumption & 55.9 & 51.2 & 216.8 \\
\hline Taxes on international trade and transactions & 24.9 & 21.3 & 111.3 \\
\hline Non-tax revenue & 26.5 & 31.6 & 104.0 \\
\hline Capital revenue & 0.0 & 0.1 & 0.0 \\
\hline Total expenditure and net lending & 153.5 & 128.5 & 663.9 \\
\hline Wages and salaries & 52.6 & 54.9 & 225.1 \\
\hline Goods and services & 22.1 & 21.1 & 108.7 \\
\hline Interest & 30.6 & 26.0 & 127.7 \\
\hline Transfers & 25.2 & 18.3 & 84.8 \\
\hline Capital expenditure and net lending & 23.0 & 8.1 & 117.7 \\
\hline Grants & 4.5 & 2.2 & 80.1 \\
\hline Overall balance $1 /$ & -23.8 & 1.2 & -59.7 \\
\hline Primary balance $1 /$ & 6.7 & 27.2 & 67.9 \\
\hline Overall balance $2 /$ & -23.9 & 19.8 & -59.7 \\
\hline Primary balance $2 /$ & 6.7 & 45.8 & 67.9 \\
\hline Statistical discrepancy, overall balance & 0.1 & -18.6 & 0.0 \\
\hline
\end{tabular}


Island Administration (NIA). ${ }^{3}$ Total revenue was largely in line with program expectations, buttressed by a strong performance of non tax revenue collected from the Citizenship-byinvestment program (CIP). Tax revenue collections, particularly from VAT and customs duties, fell somewhat short of program expectations, partly due to lower imports. More recently, the June rollover of the 365 day Treasury Bills by Nevis was successful, with a yield 25 bps lower than in the previous year.

St. Kitts and Nevis: Quantitative Performance Criteria and Indicative Targets (In EC\$ millions)

\begin{tabular}{|c|c|c|c|c|c|}
\hline & \multicolumn{5}{|c|}{ End-Mar. 2012} \\
\hline & Prog. & Adjusted & Actual & Difference & Status \\
\hline \multicolumn{6}{|l|}{ Performance Criteria: } \\
\hline Central government overall balance including grants (floor) $1 / 2$ / & -24 & -24 & 20 & 43 & met \\
\hline Stock of central government budget expenditure arrears accumulation (ceiling) 3 / & 0 & 0 & -27 & -27 & met \\
\hline Stock of external short term debt (ceiling) & 0 & 0 & 0 & 0 & met \\
\hline Central government or guaranteed external arrears accumulation (ceiling) 4/ & 0 & 0 & 0 & 0 & met \\
\hline \multicolumn{6}{|l|}{ Indicative Target: } \\
\hline Central government primary balance (floor) $1 / 2 /$ & 7 & 7 & 46 & 39 & met \\
\hline
\end{tabular}

3. All other performance criteria were met. The ceilings on central government budget expenditure arrears accumulation, the stock of external short-term debt, and the central government or guaranteed external arrears accumulation have all been met.

4. The program is consistent with the Fund's arrears policy. In staff's view, the authorities are in compliance with the Fund's policy of lending into arrears, based on their good faith efforts to engage with their private creditors.

\section{The authorities' structural reforms are on track, following completion of all} structural benchmarks (SBs) for end-March 2012 and all SBs for end-June 2012. Building on the successful completion with program SBs for end-March (Country Report No. 12/196), the authorities fulfilled their commitments in terms of structural benchmarks for end-June 2012.

\footnotetext{
${ }^{3}$ The under-execution of the capital budget was also due to an intra-year delay in disbursement of a grantfinanced project.
} 
St. Kitts and Nevis: Structural Benchmarks for March and June 2012

\begin{tabular}{|c|c|c|}
\hline Action & Target Date & Status \\
\hline Submit to Cabinet proposal to rationalize the subsidy on liquefied petroleum gas (LPG) & End-March 2012 & completed \\
\hline Submit social safety net reform strategy to Cabinet & End-March 2012 & completed \\
\hline Update the existing stress tests of banks & End-March 2012 & completed \\
\hline Update the registry of additional 600 acres of land & End-June 2012 & completed \\
\hline Undertake valuation of additional 600 acres of land & End-June 2012 & completed \\
\hline Submit draft of new Procurement Act to Parliament & End-June 2012 & completed \\
\hline Draft proposal for the establishment of an asset management company & End-June 2012 & completed \\
\hline Establish a medium-term expenditure framework with agreed fiscal targets & End-June 2012 & completed \\
\hline $\begin{array}{l}\text { Cabinet to approve a plan for civil service reform covering human resource policy, reviewing the } \\
\text { organization and structure of the civil service and addressing wage policy and payroll management }\end{array}$ & End-June 2012 & completed \\
\hline Update the existing stress tests of banks & $\begin{array}{l}\text { To be monitored on a } \\
\text { quarterly basis }\end{array}$ & completed \\
\hline
\end{tabular}

\section{Debt Restructuring}

6. The authorities progressed further on the restructuring of their public debt, building on the successful conclusion of the debt exchange with bondholders and external commercial creditors, towards the objective of reducing it from 154 percent of GDP at end-2011 to around 100 percent of GDP at end-2012 (Box 1).

7. There has been progress in terms of the debt/land swap with domestic creditors. Along with the shareholders' agreement signed on April 18, 2012, the management companies responsible for selling the land assets (Special Purpose Vehicles (SPVs)) were incorporated on April 5. In this context, an additional 754 acres of land have been registered and valued, bringing the total assessed land in the registry to 1,361 acres. The authorities intend to cancel up to about US\$333 million (441/2 percent of GDP) in domestic debt by transferring land to creditors, starting with 600 acres, through an Act of Parliament to be scheduled for the second half of 2012.

\section{The authorities concluded an agreement with their Paris Club creditors on} May 24, 2012. Total debt to Paris Club creditor countries amounted to US\$5.7 million ( 0.8 percent of GDP). The agreement establishes a flow rescheduling of 20 years with a 7 year grace period and it will reduce by over 90 percent the debt service due to Paris Club creditors during the current SBA.

\section{Policy Discussions}

9. Discussions focused on the softer near-term outlook and the role of fiscal policy in the context of limited fiscal space. Baseline projections for economic growth in 2012 have been revised from 1 percent, at the time of the second review under the SBA, to zero. Growth in tourism is expected to moderate through end-2012 due to the difficult global environment. The adverse impact on economic growth would be compensated by a slight 


\section{Bilateral creditors}

\section{Box 1. Update on the Debt Restructuring}

- On May 24, 2012, the authorities successfully concluded negotiations with Paris Club creditors. The creditors agreed on a flow rescheduling of 20 years with a 7 -year grace period, a consolidation of 93 percent of current arrears, and a full payment of moratorium interest during the consolidation period. This agreement, similar to Houston terms given to lower-middle income countries, reduces the debt service due to Paris Club creditor by over 90 percent during the current Stand-By Arrangement. The agreement also includes a goodwill clause pertaining to a future stock treatment. Specific terms are to be finalized through bilateral discussions with creditors by end-October 2012, and the authorities have initiated contacts with United Kingdom and the United States.

- Following the Paris Club agreement, the authorities resumed discussions with other bilateral official creditors, namely Kuwait, Taiwan POC, and Venezuela. The discussions are aimed at reaching comparable terms with Paris Club agreement, and are at various stages of progress.

\section{Domestic creditors}

- Debt/land swap and establishment of SPVs: Shareholders' Agreements were signed on April 18, 2012, between domestic banks and the Government of St. Kitts, and the Nevis Island Administration, respectively. Prior to the signing, two land management companies (SPVs) were established on April 5. These SPVs need to be staffed including appointment of management, and operational guidelines need to be established in accordance with international best practices to ensure transparency and accountability, including an appropriate governance structure and the plans for the sale of land in line with the limits set by the Banking Act. The registry and valuation of additional 600 acres of land has been completed, and the transfer of land to SPVs is planned to be completed by end-September 2012 through an Act of Parliament. Once the SPVs become operational, the existing public land sales and development agencies will be rationalized (SB for end-September 2012).

- Debt not covered by debt/land swap: Discussions on debt not covered by the debt/land swap continue with other banks, taking into account the specifics of the respective banks' balance sheet and operations. The discussions are based on the principle of reaching an agreement on comparable terms to those already concluded, and in line with contributing to a sustainable debt trajectory.

- Debt held by the Social Security Board: Negotiations are still ongoing with Social Security Board, with aims to preserve its long-term sustainability and taking into account the contingent liability it could pose to the government.

\section{Medium-term Debt Sustainability with Indicative Debt Restructuring Scenario}

- In addition to the baseline scenario, this assumes: (1) Paris Club and other official bilateral creditors: in line with, or at least as favorable terms as, the Paris Club agreement reached, (2) Remaining eligible domestic creditors: repayment schedule in line with the par bond issued for the exchange in April 2012, with somewhat more favorable coupon rates, and (3) Debt-land swap: covering roughly EC $\$ 900$ million, with 3.5 percent guaranteed dividend over the first three years on part of the unsecured debt.

- Outcome: The simulation suggests an initial sharp step-down in level of public debt from 154 percent of GDP to just under 100 percent of GDP and decline to below 60 percent by 2020 . This could result in potential reduction in interest payments of about EC $\$ 40-50$ million on average per year.

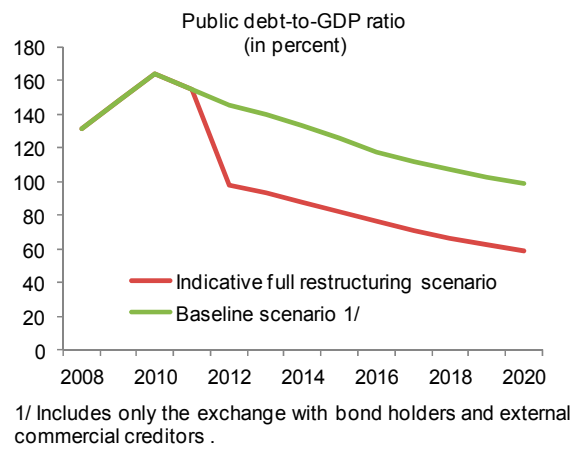


recovery of construction in the remainder of 2012 while external conditions will continue to present downside risks. In order to support growth while safeguarding fiscal targets, the authorities are committed to accelerating capital spending on infrastructure within the existing budgetary framework, intensifying measures to secure tax revenue, and continuing to control spending (MEFP $\mid 6$ ).

10. Over the medium-term, growth is projected to pick up, partly owing to large real estate development projects financed by FDI. Real GDP growth is projected to reach $13 / 4$ percent for 2013 and 4 percent over the medium term. Construction activity is envisaged to rebound in the next few years, driven by sizeable tourism development projects already in the pipeline. Financing for some of these projects has been identified, and relatedconstruction activities are expected to commence before end-2012.

\section{A. Fiscal Policy}

\section{Despite the dampened growth outlook, the authorities maintain their} commitment to the $\mathbf{2 0 1 2}$ program target of an overall fiscal deficit of EC\$60 million.

The program target remains achievable given the projected continued strong performance of the non-tax revenue generated by the CIP for the remainder of the year. In addition, revenue administration will be intensified to shore up tax collections and capital spending on infrastructure will be accelerated within the budget allocation to help sustain growth. (MEFP $\mid 6)$.

\section{The authorities continue to strengthen revenue administration and are} considering options to broaden the tax base (MEFP 17 and 98 ). Administrative enhancements that should significantly improve the revenue yield of the existing tax system include: the implementation of the Tax Roll and Intelligence Unit at the Inland Revenue Department (IRD) and structures to cross-reference taxpayer declarations made to the IRD and the Customs Department and contributions made to the Social Security Board; the computerization of payments and reports; and the clarification of guidelines on investigation techniques. In addition, staff and the authorities agreed that additional tax revenue could be secured by broadening the tax base, building on recent advances, through a re-examination of the system of customs duty and tax exemptions (MEFP $\$ 6$ ) and its improved targeting. ${ }^{4}$

13. Given the limited fiscal space for growth-enhancing public expenditure, the authorities intend to continue the freeze on the wage bill and the cap on growth in expenditure on goods and services (MEFP q9). Measures to improve the efficiency of public expenditure include the upcoming closure of the St. Kitts government-run Supply Office (responsible for purchasing staple commodities and administering their prices).

\footnotetext{
${ }^{4}$ At the second review under the SBA, the authorities have committed to review all existing customs duties exemptions by end-June 2013 and tax exemptions by end-2013 (EBS 12/61, MEFP $₫ 10$ ).
} 


\section{Staff and the authorities agree on the importance of pressing ahead with} structural reforms in public financial management in order to further improve the efficiency of public spending (MEFP \$10). Swift implementation of the procurement law will be critical, as will be the reform of the civil service over the medium-term. To further contain the contingent liabilities of public enterprises, building on existing limits placed on their overdraft facilities, the Government Entities Oversight Board will be formalized and its enforcement capacity will be strengthened (structural benchmark for end-March 2013). In order to improve the efficiency of the social safety net, the authorities initiated a rationalization of existing cash transfer programs with improved targeting to the neediest and expect to define their eligibility criteria by end-September 2013 (structural benchmark). Staff and the authorities agreed on the importance of improving the Public Sector Investment Program by refining the selection criteria of the investment projects and better aligning them with sectoral strategies and strengthening the monitoring of their execution. Concerning the structural benchmark for the Social Security Scheme, the authorities are proposing that the target date for its review could be postponed from end-September 2012 to end-December 2012, on account of administrative delays (MEFP $\mid 12){ }^{5}$

\section{B. Debt Restructuring}

15. The authorities are moving ahead with various strands of the debt restructuring. A critical next step in the conversion into land assets of domestic loans contracted by the government is the operational implementation of the SPV. In particular, staff recommended and the authorities agreed to use international advertising for recruiting key personnel, with possible TA support from a relevant international agency. Furthermore, the authorities intend to apply best practices in defining the mode of operation of the company, including with respect to its transparency and accountability (MEFP $\mid 4$ ). The authorities agreed that a relatively quick pace of land sales will be key in safeguarding the financial position of domestic creditors. Following up on the general agreement with Paris Club creditors, the authorities expect to bilaterally reach agreement on specific terms with the United Kingdom and the United States soon and have approached their other bilateral and domestic creditors (MEFP q2).

16. The authorities are collaborating closely with the ECCB to address any repercussion on the financial sector from the debt/land swap. In that regard, the updated stress tests prepared quarterly by the ECCB have been particularly helpful. The ECCB indicated that it continues to monitor closely the domestic banks most exposed to government debt and impacted by the swap. The relevant banks indicated that they are undertaking measures to develop other sources of income, such as the processing of credit cards and the extension of this service within the region. The domestic banks do not envisage

\footnotetext{
${ }^{5}$ The delay was related to the administrative process for contracting an actuary.
} 
that their liquidity and profitability situation will be exacerbated following the debt/land swap, as they see the land as being in high demand and envisage that it will be sold relatively quickly.

\section{Program Design}

17. The authorities laid out in the attached Letter of Intent (LOI) and Memorandum of Economic and Financial Policies (MEFP) their continued commitment to the program objectives. The program's conditionality envisages adding two new structural benchmarks and resetting the target date for the review of the Social Security Scheme from end-September 2012 to end-December 2012; as noted in paragraph 14 (MEFP, Table 4).

18. No significant risks were identified by the updated safeguards assessment of the ECCB which was completed on April 16, 2012. The ECCB has already taken steps towards implementing recommendations to maintain and advance its safeguards framework. In addition, the authorities are committed to formalize the safeguards policy requirement to hold foreign exchange balances only with the central bank (MEFP \ 5).

\section{Program Risks}

19. The successful program implementation to date and progress in debt restructuring have further improved the capacity of St. Kitts and Nevis to repay the IMF (Table 8). Debt service to the Fund will peak in 2016 at 3.6 percent of GDP and 11.8 percent of exports of goods and services before falling significantly in the following years. St. Kitts and Nevis should be in a solid position to repay the IMF, based on the maintenance of a strong fiscal framework and the savings generated by the debt restructuring. Successful implementation of structural reforms to enhance fiscal space should further strengthen that position by dampening the impact on debt dynamics by exogenous shocks; reducing unforeseen expenditure pressures caused by natural disasters and contingent liabilities; and limiting financial sector vulnerabilities.

\section{StafF Appraisal}

20. The authorities of St. Kitts and Nevis have continued to assiduously and successfully pursue their economic program despite softer growth and continued global uncertainty. All program performance criteria and structural benchmarks were met at end-March 2012. Structural benchmarks for end-June were also met. Significant progress was also achieved in the debt restructuring agenda, with the incorporation of the SPV and the agreement reached with Paris Club creditors.

21. A prompt completion of the government's debt restructuring will set the stage for a sustainable debt trajectory and yield debt service savings which could be reallocated to priority infrastructure spending. In that regard, it is hoped that progress could be made in terms of the bilateral agreements with Paris Club creditors as well as 
successful negotiations with other bilateral creditors. Furthermore, the SPV, central to the domestic debt restructuring, needs to become operational soon and according to best practices, in order for land sales to get underway. This prompt undertaking would minimize the impact on the financial sector. In addition to pursuing new income sources, the banking sector should be encouraged to reduce its non-performing loans more vigorously in order to provide a boost to both liquidity and profitability.

\section{An acceleration of budgeted capital spending on infrastructure will help}

promote some short-term stimulus. The authorities correctly recognize the importance of sustaining growth through upgrades in public infrastructure, and there is some intra-year room to do so in 2012.

23. A robust and growing source of tax revenue and continued enhancements to the efficiency of public expenditure are needed to reach medium-term fiscal goals. Given the likely transitory nature of receipts from the Citizenship by Investment program and the Sugar Industry Diversification Foundation (SIDF), it will be critical to continue to bolster tax revenue over the medium-term. In order to promote economic growth, improving the yield of the tax system should be undertaken through further administrative reforms and broadening of the tax base. The authorities' initiatives in that respect, including the review and planned rationalization of tax incentives, are appropriate. The authorities are also justified to seek further fiscal consolidation by improving the efficiency of expenditure through streamlining current outlays and reforming public financial management. In addition to reducing public debt over the medium-term, the fiscal consolidation may also provide additional resources to address unforeseen contingencies and accelerate investment in infrastructure, which is critical for growth.

24. Based on the authorities' demonstrated commitment to the program and successful implementation, staff supports the request for completion of the third review under the SBA and the financing assurances review. Staff is of the view that the observance of the end-June 2012 PCs is achievable notwithstanding the unavailability of the necessary information to date. Accordingly, staff supports the request for waivers of applicability. 
Figure 1. St. Kitts and Nevis: Selected Economic Indicators

Economic growth has been revised from 1 percent, at the time of the second SBA review, to zero in 2012.

Contribution to GDP Growth in St. Kitts and Nevis (In percentage points)

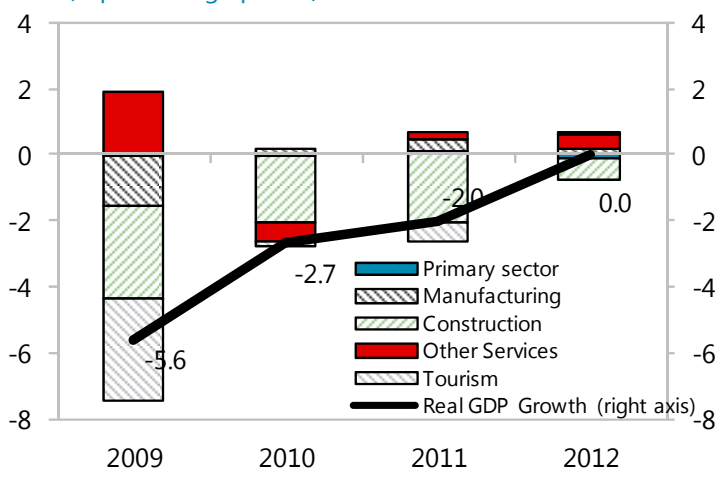

Tourism activity rebounded in 2012 Q1, owing to a strong first quarter growth in stay-over visitors...

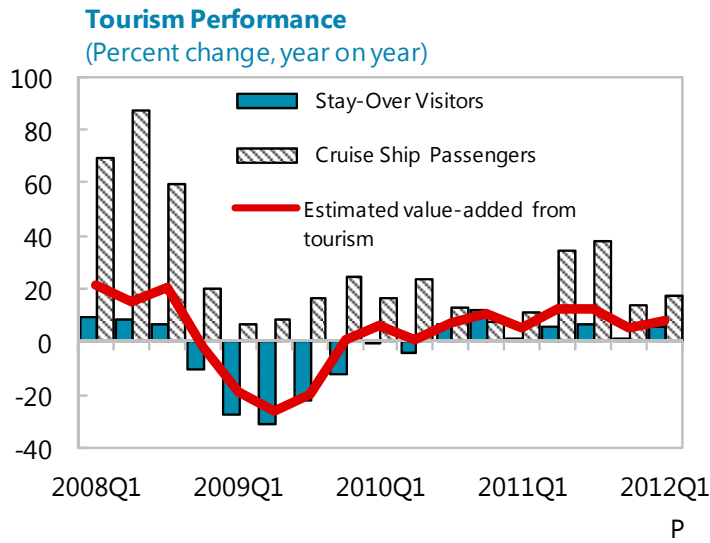

External competitiveness has improved modestly in the recent past.

Effective Exchange Rates (Index 2005=100) 1 /

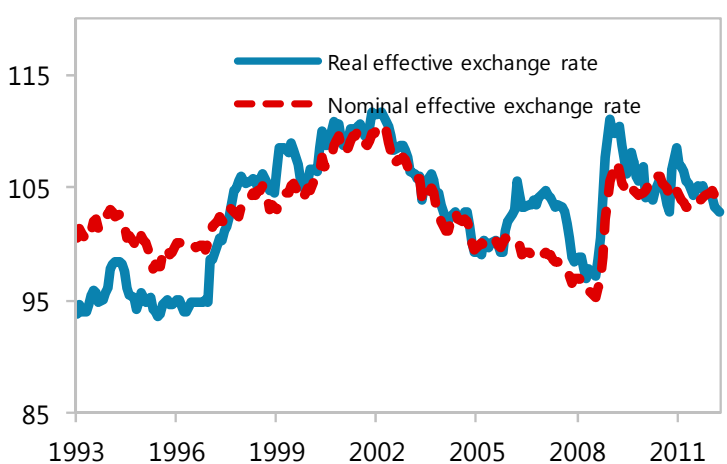

Construction has been on a steady decline since 2008.

Real Construction GDP

(In EC\$ 2006 prices)

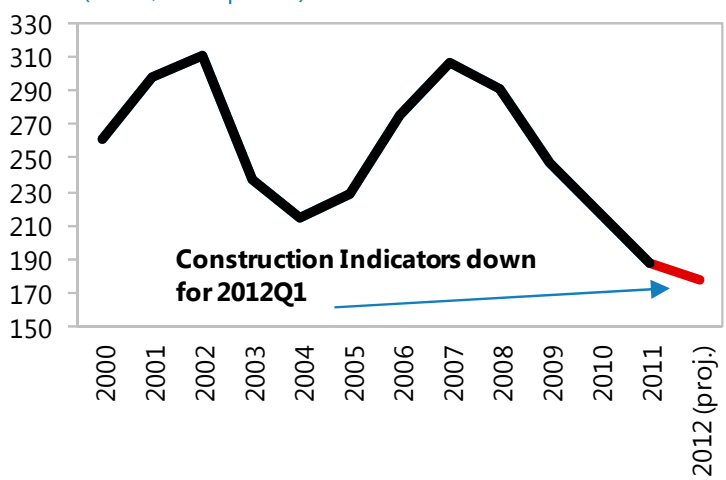

...however, recent declines in US wealth suggest limited capacity for American visitors (60 percent of total) to rebound in the medium term.

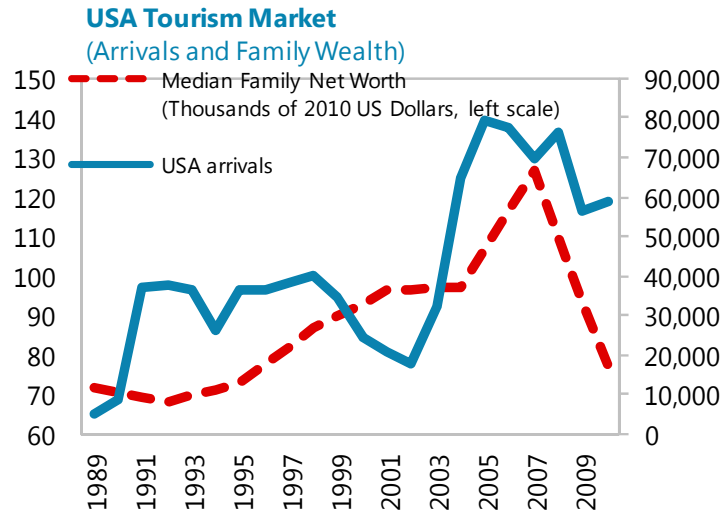

Exports and tourism receipts improved during the first quarter of 2012 while imports continued to slide.

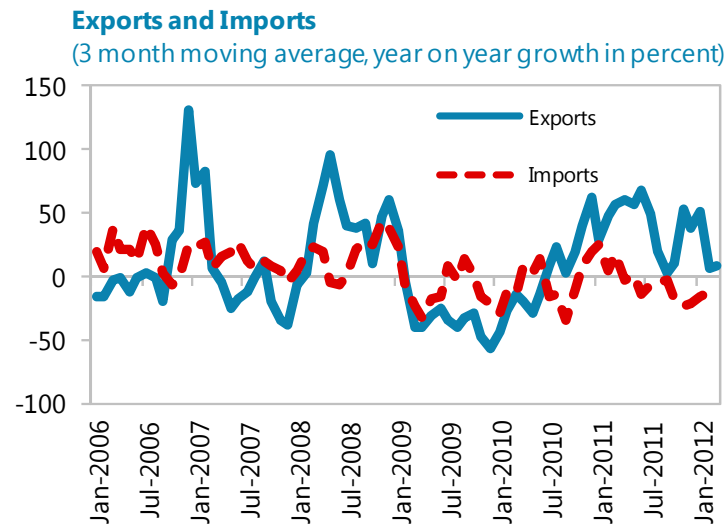

Source: ECCB; country authorities; and IMF staff calculations.

${ }^{1 /}$ An increase (decrease) indicates and appreciation (depreciation). 
Figure 2. St. Kitts and Nevis: Fiscal Developments

The fiscal outturn for 2012 Q1 was aligned with expectations as the tax revenue shortfall was offset by strong non-tax revenue and significant cut backs in capital expenditure.

Central Government, 2012Q1

(EC\$ million)

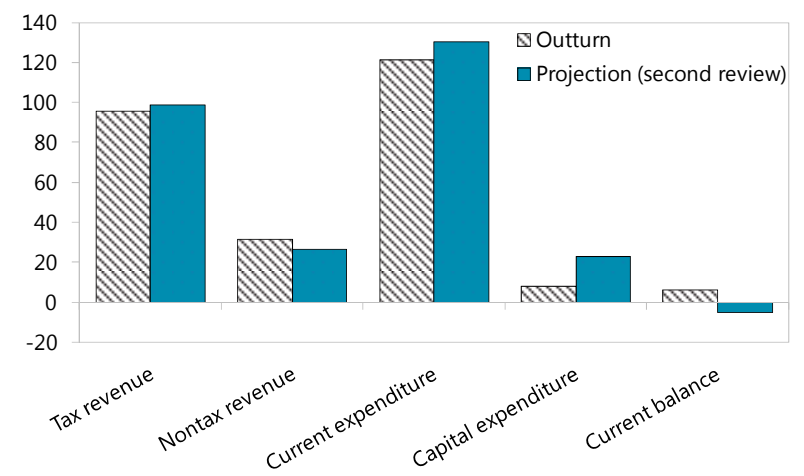

All categories of current expenditure were only slightly down during the first quarter of 2012 relative to the first quarter of 2011.

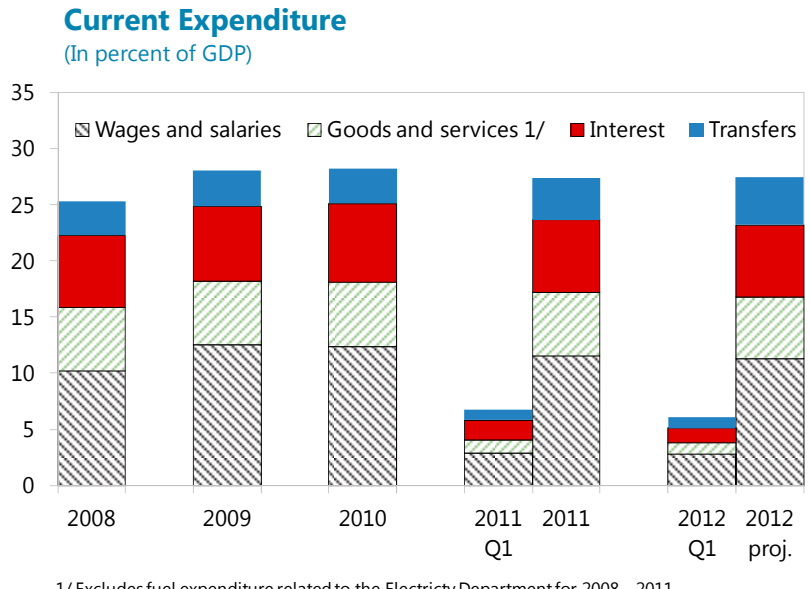

1/ Excludes fuel expenditure related to the Electricty Department for 2008 - 2011

Government is on course to meet its targets for 2012.

Central Government Primary Balance Including Grants (EC\$ million)

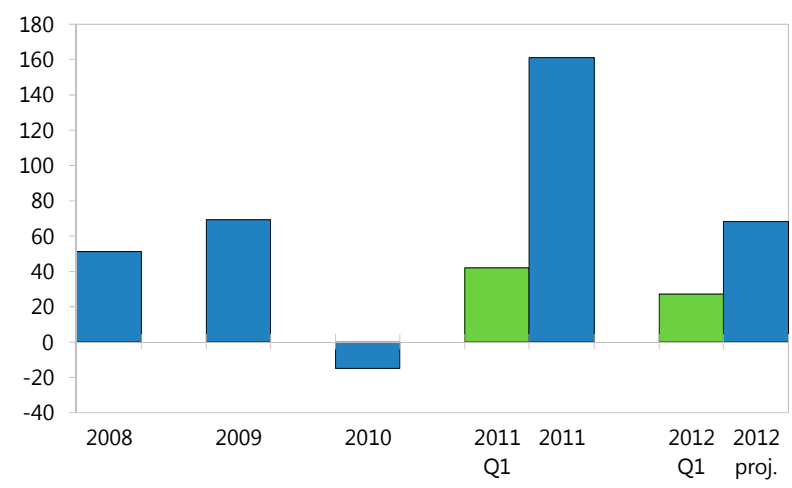

Sources: St. Kitts and Nevis authorities; and IMF staff estimates and projections 
Figure 3. St. Kitts and Nevis: Developments in the Local Banking System, 2010-12 ${ }^{1 /}$

Liquidity has increased in 2012 Q1.

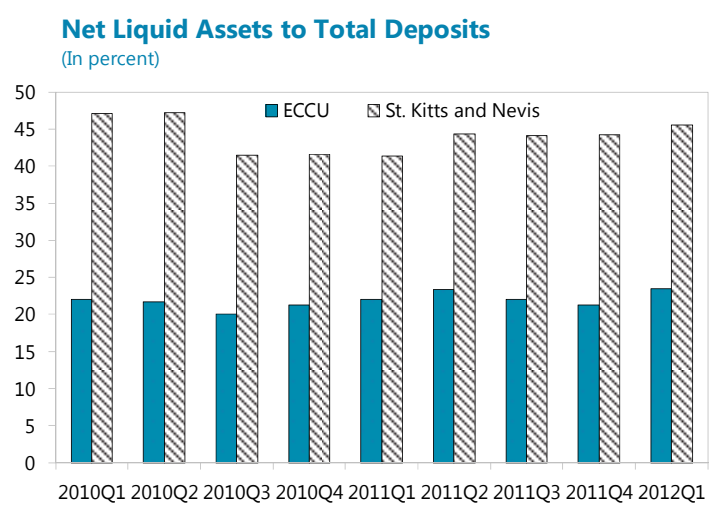

Nonperforming loans remain relatively low by regional norms, but above the ECCB benchmark of 5 percent.

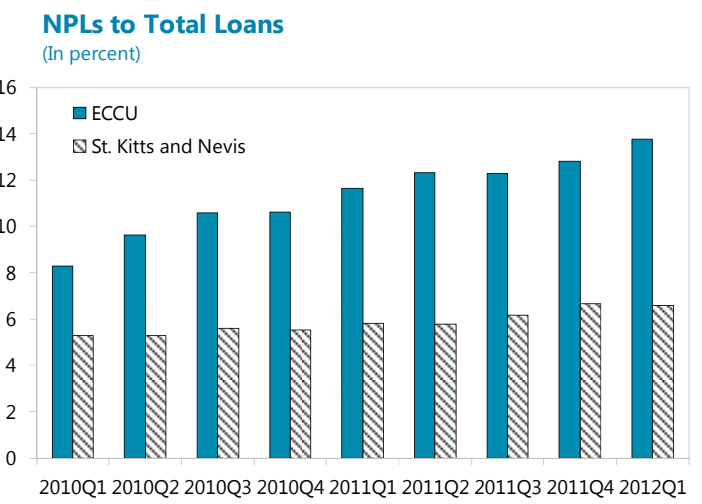

Private deposits increased by more than credit to the private sector since August 2011.

Private Sector Credit and Deposits

(Change since end-December 2008, in EC\$ million)

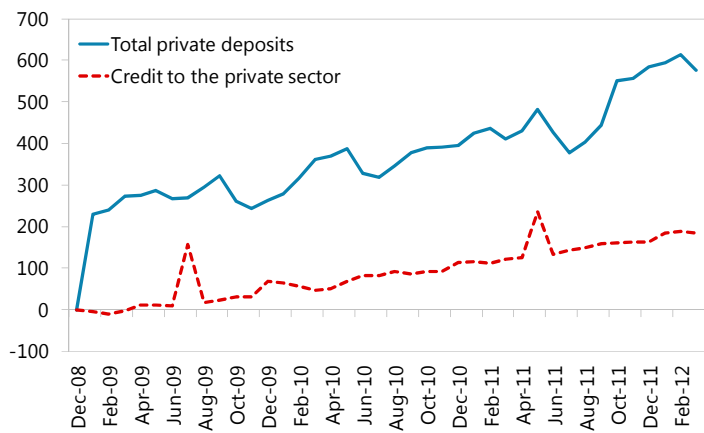

Capital buffers have declined but remain adequate, particularly by regional standards.

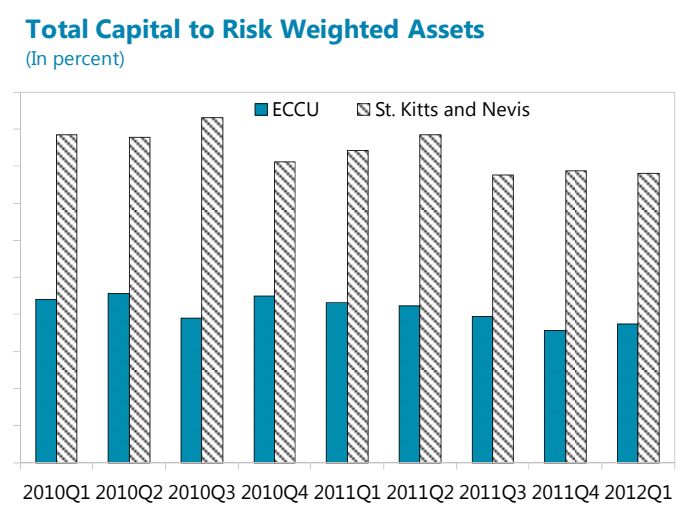

Provisioning for loan losses improved in 2012QI.

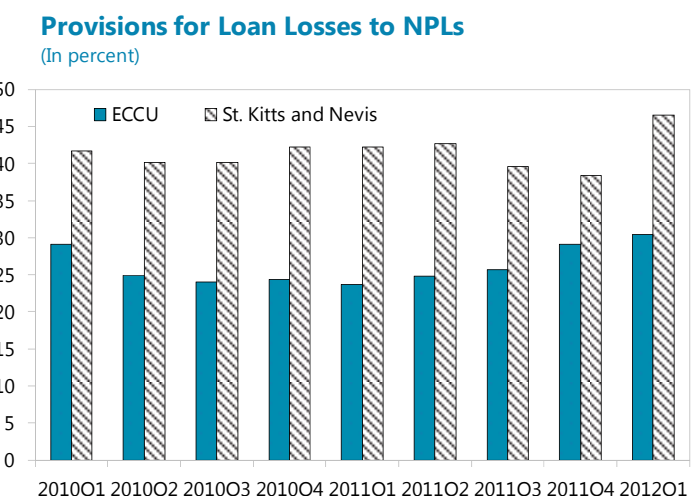

Spreads between interest rates on loans and interest rates on deposits have widened.

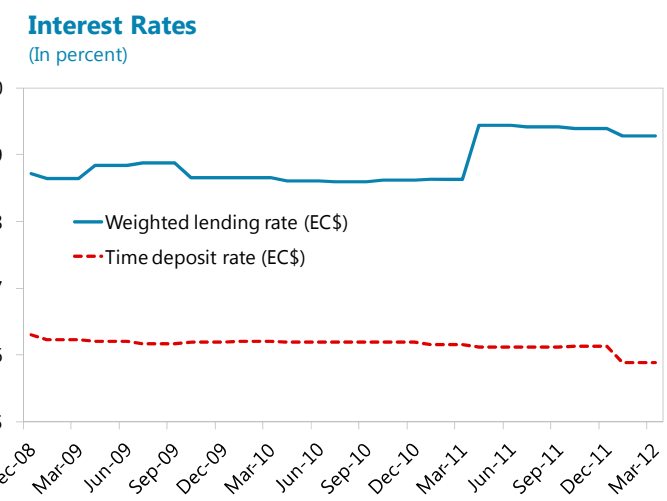

Sources: ECCB; and IMF staff calculations.

1/ includes locally incorporated foreign banks. 
Figure 4. St. Kitts and Nevis: External Debt Sustainability: Bound Tests 1/ 2/3/ (External debt in percent of GDP)

Baseline and historical scenarios

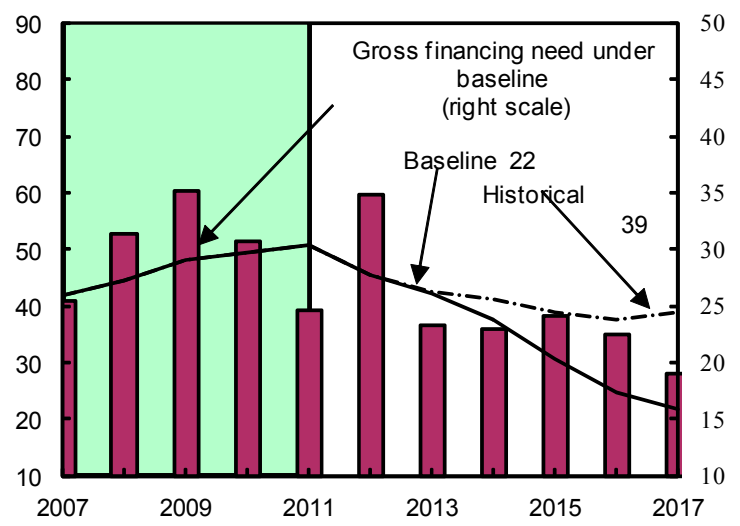

Growth shock (in percent per year)

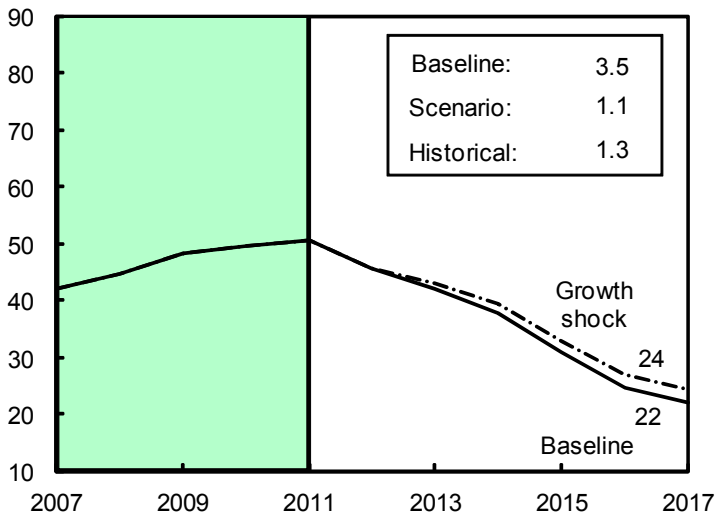

Combined shock 4/

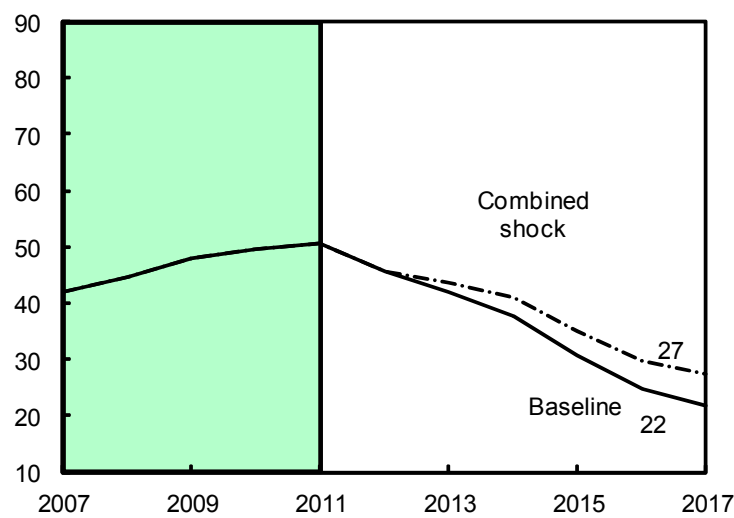

Interest rate shock (in percent)

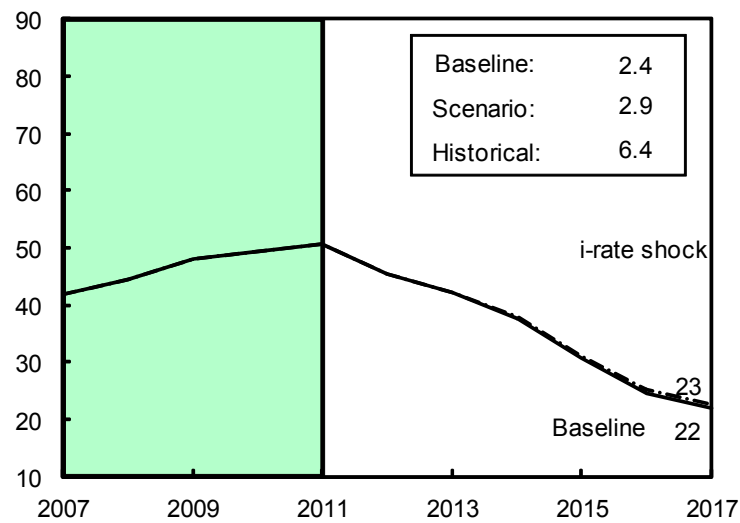

Non-interest current account shock (in percent of GDP)

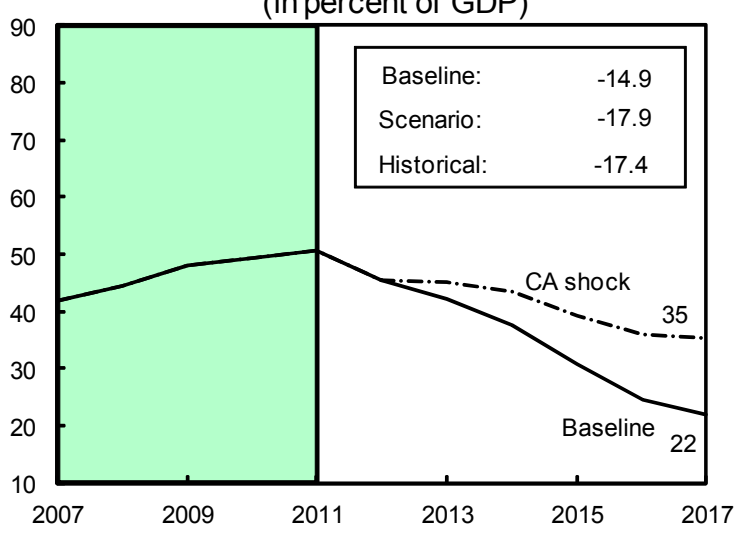

Real depreciation shock 5/

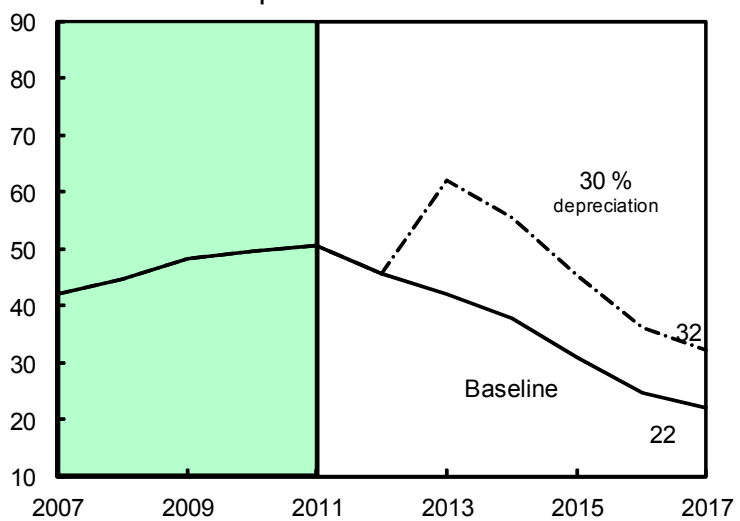

Sources: International Monetary Fund, St. Kitts and Nevis authorities, and staff estimates.

$1 /$ Reflects the outcome of the debt exchange offer to bondholders and external commercial creditors.

2/ Shaded areas represent actual data. Individual shocks are permanent one-half standard deviation shocks. Figures in the boxes represent average projections for the respective variables in the baseline and scenario being presented. Tenyear historical average for the variable is also shown.

3/ For historical scenarios, the historical averages are calculated over the ten-year period, and the information is used to project debt dynamics five years ahead.

4/ Permanent 1/4 standard deviation shocks applied to real interest rate, growth rate, and current account balance in 2013.

5/ One-time real depreciation of 30 percent occurs in 2013. 
Figure 5. St. Kitts and Nevis: Public Debt Sustainability: Bound Tests 1/2/3/ (Public debt in percent of GDP)
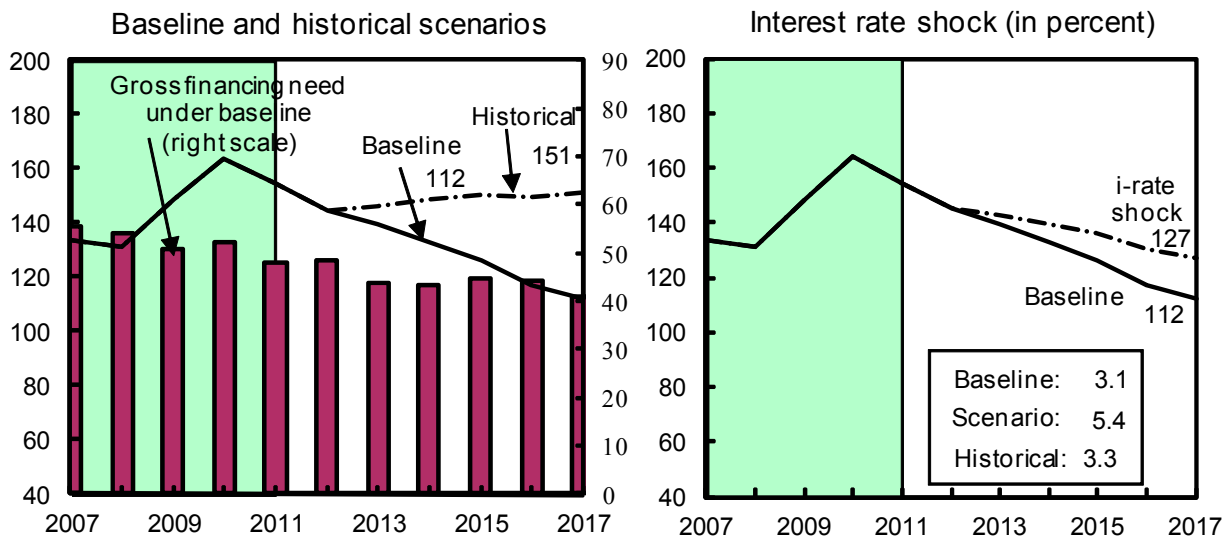

Growth shock (in percent per year)

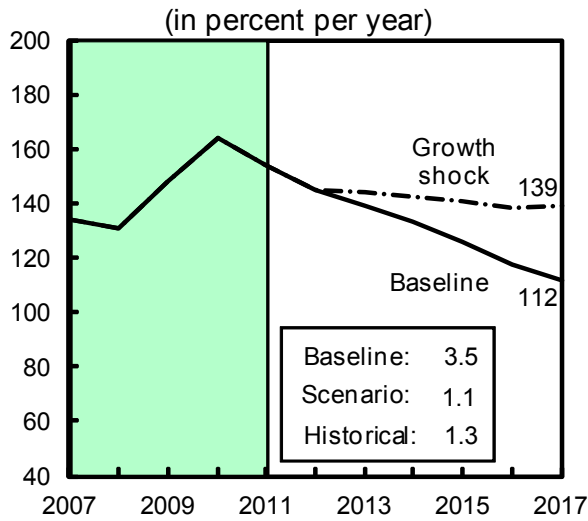

Primary balance shock (in percent of GDP) and no policy change scenario (constant primary balance)

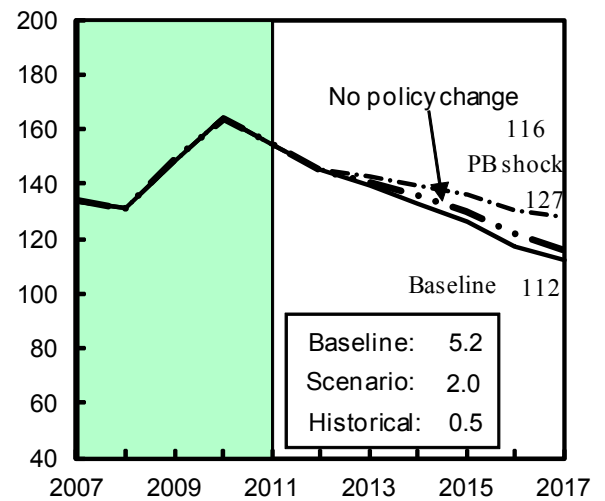

Combined shock 4/

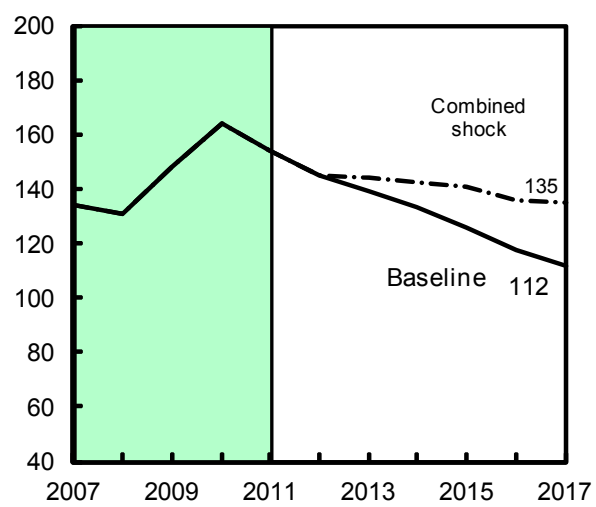

Real depreciation and contingent liabilities shocks 5/

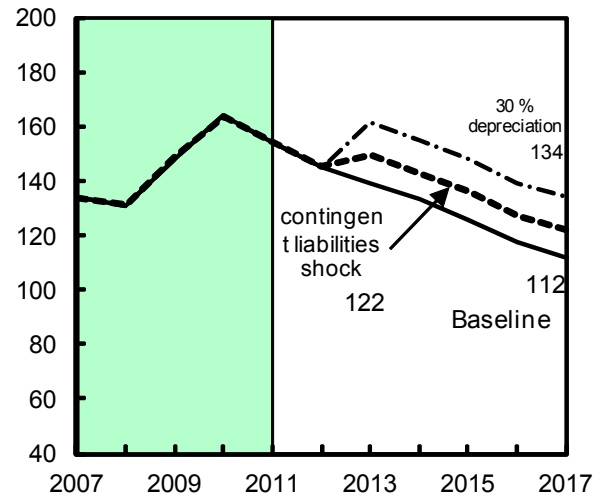

Sources: Intemational Monetary Fund, St. Kitts and Nevis authorities, and staff estimates.

$1 /$ Reflects the outcome of the debt exchange offer to bondholders and external commercial creditors. $2 /$ Shaded areas rep resent actual data. In dividual shocks are permanent one-half standard deviation shocks. Figures in the boxes represent average projections for the respective variables in the baseline and scenario being presented. Ten-year historical average for the variable is al so shown.

$3 /$ For historical scenarios, the historical averages are calculated over the ten-year period, and the information is used to project debt dynamics five years ahead.

4/ Permanent $1 / 4$ standard deviation shocks ap plied to real interest rate, growth rate, and primary balance. $5 /$ One-time real depreciation of 30 percent and 10 percent of GDP shock to contingent liabilities occur in 2013, with real depreciation defined as nominal depreciation (measured by percentage fall in dollar value of local curren cy) minus domestic inflation (based on GDP deflator). 
Table 1. St. Kitts and Nevis: Basic Data

Area (sq. km)

Population

Total (thousands, 2001)

Rate of growth (percent per year, 2001)

Density (per sq. km., 2001)

Net migration rate (per thousand, 2002)

Population characteristics (2008)

Life expectancy at birth (years)

Infant mortality (per thousand live births)

Under 5 mortality rate (per thousand)
I. Social, Geographic and Demographic Indicators

269.4

Adult literacy rate (percent, 2009)

97.8

Health and nutrition

$46.1 \quad$ Calorie intake (per capita a day, 2011) 2,452

0.02 Population per physician (thousand, 2000)

171.2 Access to safe water (percent, 2008)

AIDS incidence rate (per 100,000, 2011)

Gross domestic product (2011)

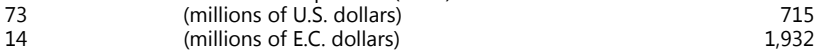

$\begin{array}{llr}14 & \text { (millions of E.C. dollars) } & 1,932 \\ 15 & \text { (US\$ per capita) } & 12,728\end{array}$

II. Economic and Financial Indicators, 2007-13

\begin{tabular}{|c|c|c|c|c|c|c|c|c|}
\hline & 2007 & 2008 & 2009 & 2010 & $\begin{array}{r}\text { Prel. } \\
2011 \\
\end{array}$ & $\begin{array}{r}\text { Prog. 1/ } \\
2012 \\
\end{array}$ & $\begin{array}{l}\text { Proj. } \\
2012 \\
\end{array}$ & $\begin{aligned} \text { Proj. } \\
2013 \\
\end{aligned}$ \\
\hline \multicolumn{9}{|c|}{ (Annual percentage change; unless otherwise specified) } \\
\hline National income and prices & & & & & & & & \\
\hline Real GDP (factor cost) & 5.0 & 4.0 & -5.6 & -2.7 & -2.0 & 1.0 & 0.0 & 1.8 \\
\hline Consumer prices, end-of-period & 2.9 & 6.5 & 1.2 & 5.2 & 2.9 & 2.1 & 1.9 & 2.5 \\
\hline Consumer prices, period average & 4.5 & 5.3 & 2.1 & 0.6 & 7.1 & 2.8 & 2.5 & 2.5 \\
\hline Real effective exchange rate (end-of-period) $2 /$ & -5.5 & 12.8 & -3.8 & 1.6 & -3.7 & $\ldots$ & $\ldots$ & $\ldots$ \\
\hline \multicolumn{9}{|l|}{ Banking system } \\
\hline Net foreign assets $3 /$ & 6.9 & 11.6 & -8.4 & 1.1 & 10.5 & 2.9 & 2.9 & 0.7 \\
\hline $\begin{array}{l}\text { Net domestic assets } 3 / \\
\text { Of which }\end{array}$ & 5.0 & -10.0 & 14.3 & 7.8 & -0.5 & 1.1 & 0.2 & 3.8 \\
\hline Credit to private sector $3 / 4$ / & 8.6 & 4.3 & 4.1 & 2.6 & 2.6 & 2.6 & 1.5 & 4.3 \\
\hline Broad money 4/ & 11.9 & 1.6 & 5.9 & 8.9 & 10.0 & 4.0 & 3.1 & 4.5 \\
\hline Of which & & & & & & & & \\
\hline Money & 12.2 & 11.4 & -3.1 & 43.1 & 34.7 & 4.0 & 3.1 & 4.5 \\
\hline Quasi-money & 11.9 & 0.0 & 7.5 & 3.3 & 4.4 & 4.0 & 3.1 & 4.5 \\
\hline \multicolumn{9}{|c|}{ (In percent of GDP) } \\
\hline Public sector 5/ & & & & & & & & \\
\hline Primary balance & 2.7 & 2.6 & 3.7 & -0.8 & 8.3 & 3.4 & 3.4 & 4.5 \\
\hline Overall balance & -3.5 & -3.9 & -2.9 & -7.8 & 1.8 & -3.0 & -3.0 & -1.1 \\
\hline Revenue & 27.8 & 27.2 & 29.0 & 28.2 & 33.6 & 26.1 & 26.3 & 27.2 \\
\hline Grants & 1.5 & 1.4 & 3.6 & 2.8 & 3.5 & 4.0 & 4.0 & 2.1 \\
\hline Current expenditure & 26.7 & 27.3 & 30.4 & 31.7 & 31.0 & 27.2 & 27.4 & 25.3 \\
\hline Capital expenditure and net lending & 6.1 & 5.3 & 5.1 & 7.1 & 4.4 & 5.8 & 5.9 & 5.1 \\
\hline Foreign financing 6 / & -1.2 & 3.5 & 0.2 & 0.3 & 0.3 & -6.3 & -5.7 & -4.6 \\
\hline Domestic financing & 2.8 & -2.5 & 3.1 & 7.5 & -4.6 & -5.3 & -5.4 & -0.3 \\
\hline Change in arrears & & 1.2 & 1.3 & 1.0 & 1.6 & -1.6 & -1.6 & 0.0 \\
\hline Sale of assets & 2.0 & 3.1 & 1.7 & 0.7 & 0.4 & 0.2 & 0.2 & 0.2 \\
\hline Potential extraordinary financing & & & & & & 13.4 & 13.2 & 3.9 \\
\hline Statistical discrepancy & 0.0 & -1.4 & -3.3 & -1.7 & 0.4 & - & - & - \\
\hline Financing gap & & & & & & 2.6 & 2.2 & 1.9 \\
\hline $\begin{array}{l}\text { Total public debt (end-of-period) } \\
\text { Of which }\end{array}$ & 134.0 & 131.0 & 148.5 & 163.9 & 154.3 & 143.9 & 144.9 & 139.5 \\
\hline $\begin{array}{l}\text { Of which } \\
\text { Central government 7/ }\end{array}$ & & & & & & & & \\
\hline $\begin{array}{l}\text { Central government 7/ } \\
\text { Public enterprises } 7 /\end{array}$ & 101.5 & 100.5 & 114.9 & 129.4 & 123.1 & 115.4 & 115.7 & 111.6 \\
\hline Public enterprises 7/ & 32.5 & 30.5 & 33.5 & 34.4 & 31.2 & 28.5 & 29.2 & 27.9 \\
\hline Public debt service (percent of total revenue and grants) 6/ & 30.1 & 28.4 & 25.2 & 29.1 & 22.3 & 62.2 & 62.9 & 24.8 \\
\hline \multicolumn{9}{|l|}{ External sector } \\
\hline External current account balance & -16.7 & -24.3 & -27.3 & -22.1 & -15.2 & -18.9 & -17.1 & -16.4 \\
\hline Trade balance & -26.4 & -29.3 & -33.8 & -32.4 & -27.3 & -26.2 & -25.2 & -24.8 \\
\hline Tourism receipts & 18.1 & 14.9 & 12.1 & 13.4 & 12.5 & 12.6 & 130 & 13.4 \\
\hline Transfers, net & 4.2 & 4.5 & 6.6 & 6.9 & 6.7 & 4.9 & 4.9 & 4.5 \\
\hline Net capital inflow 8/ & 17.7 & 25.1 & 27.9 & 26.0 & 15.7 & 5.4 & 3.4 & 10.8 \\
\hline FDI (net) & 19.5 & 24.0 & 19.0 & 19.9 & 15.9 & 16.0 & 13.3 & 15.7 \\
\hline External financing gap 9/ & & & & & & 1.0 & 1.0 & 0.7 \\
\hline External public debt (end-of-period) & 41.9 & 44.6 & 48.1 & 49.5 & 50.7 & 45.2 & 45.5 & 42.1 \\
\hline \multicolumn{9}{|c|}{ (In percent of exports of goods and nonfactor services) } \\
\hline External public debt service & 21.0 & 18.8 & 23.9 & 21.6 & 22.4 & 26.2 & 25.7 & 25.0 \\
\hline External public debt (end-of-period) & 125.3 & 143.4 & 195.5 & 167.2 & 161.5 & 160.5 & 157.2 & 143.3 \\
\hline \multirow{2}{*}{\multicolumn{9}{|c|}{$\begin{array}{l}\text { Memorandum items } \\
\text { Gross international reserves, end-ot-period }\end{array}$}} \\
\hline & & & & & & & & \\
\hline (in millions of U.S. dollars) & 95.6 & 110.2 & 122.9 & 155.7 & 196.0 & 194.2 & 194.3 & 192.5 \\
\hline (in percent of broad money) & 15.9 & 18.0 & 19.0 & 22.1 & 25.3 & 24.1 & 24.3 & 23.0 \\
\hline Holdings of SDRs, in millions of U.S. dollars & $\ldots$ & $\ldots$ & 13.3 & 12.8 & 12.8 & 12.8 & 12.8 & 13.8 \\
\hline Nominal GDP at market prices (in millions of EC\$) & 1,862 & 1,998 & 1,859 & 1,818 & 1,932 & 2,009 & 1,992 & 2,082 \\
\hline
\end{tabular}

Sources: St. Kitts and Nevis authorities; ECCB; UNDP; World Bank; and Fund staff estimates and projections.

$1 /$ Second review under SBA, EBS 12/61.

2/ Weights given by the average trade share during 1999-2003. Depreciation (-).

3 / In relation to broad money at the beginning of the period.

4/ Data from 2009 includes non-bank financial institutions and subsidiaries and affiliates as parts of private sector to reflect the changes in definition in Jan 2009.

5/ Central government unless otherwise noted. Primary and overall balances are based on above-the-line data.

$6 / 2012$ disbursement includes financing to regularize the external arrears related to fuel purchases.

7/ SSMC debt included in central government debt since 2006.

8/ Includes errors and omissions.

9/ Net of IMF financing and debt forgiveness. 
Table 2. St. Kitts and Nevis: Central Government Fiscal Operations, 2008-17 1/

(In millions of Eastern Caribbean dollars)

\begin{tabular}{|c|c|c|c|c|c|c|c|c|c|c|c|}
\hline & & & & Prel. & Prog. $2 /$ & Rev. proj. & & & Proj. & & \\
\hline & 2008 & 2009 & 2010 & 2011 & 2012 & 2012 & 2013 & 2014 & 2015 & 2016 & 2017 \\
\hline Total revenue & 544.4 & 539.4 & 513.5 & 651.1 & 524.1 & 524.1 & 566.2 & 598.8 & 633.3 & 671.8 & 712.4 \\
\hline Current revenue & 544.4 & 539.4 & 513.5 & 650.0 & 524.1 & 524.1 & 566.2 & 598.8 & 633.3 & 671.8 & 712.4 \\
\hline Tax revenue & 422.0 & 396.1 & 342.4 & 408.1 & 420.2 & 414.7 & 448.8 & 474.9 & 505.6 & 539.9 & 576.6 \\
\hline Taxes on income & 135.7 & 148.7 & 92.6 & 86.6 & 81.5 & 85.5 & 89.1 & 94.3 & 100.4 & 107.2 & 114.5 \\
\hline Taxes on property & 6.6 & 8.8 & 9.4 & 8.8 & 10.6 & 12.0 & 11.8 & 12.5 & 13.3 & 14.2 & 15.2 \\
\hline Taxes on domestic goods and consumption $3 /$ & 83.9 & 69.6 & 84.2 & 208.3 & 216.8 & 214.2 & 231.5 & 245.0 & 260.9 & 278.6 & 297.5 \\
\hline Taxes on international trade and transactions & 195.9 & 169.0 & 156.3 & 104.4 & 111.3 & 102.9 & 116.3 & 123.0 & 131.0 & 139.9 & 149.4 \\
\hline Nontax revenue & 122.5 & 143.3 & 171.0 & 241.9 & 104.0 & 109.4 & 117.4 & 123.9 & 127.7 & 131.8 & 135.8 \\
\hline Capital revenue & 0.0 & 0.0 & 0.0 & 1.1 & 0.0 & 0.0 & 0.0 & 0.0 & 0.0 & 0.0 & 0.0 \\
\hline Total expenditure and net lending & 650.4 & 661.1 & 706.1 & 684.5 & 663.9 & 663.9 & 633.2 & 648.6 & 685.5 & 734.4 & 787.2 \\
\hline Current expenditure & 545.3 & 565.6 & 576.3 & 598.8 & 546.4 & 546.3 & 527.4 & 536.7 & 563.3 & 604.0 & 644.5 \\
\hline Wages and salaries & 204.5 & 233.5 & 224.0 & 222.0 & 225.1 & 225.1 & 225.1 & 230.7 & 241.9 & 257.7 & 275.2 \\
\hline Goods and services 4/ & 151.8 & 150.1 & 169.1 & 179.7 & 108.7 & 108.7 & 109.4 & 112.6 & 119.9 & 128.0 & 136.7 \\
\hline Interest & 128.7 & 123.2 & 127.0 & 126.0 & 127.8 & 127.7 & 115.9 & 115.1 & 120.0 & 131.1 & 139.5 \\
\hline Domestic & 86.8 & 81.6 & 86.7 & 91.6 & 101.7 & 101.7 & 94.7 & 98.1 & 104.4 & 117.7 & 127.6 \\
\hline Foreign & 41.9 & 41.6 & 40.3 & 34.4 & 26.1 & 26.0 & 21.2 & 17.0 & 15.5 & 13.4 & 11.9 \\
\hline Transfers & 60.3 & 58.9 & 56.2 & 71.1 & 84.8 & 84.8 & 77.0 & 78.3 & 81.6 & 87.1 & 93.1 \\
\hline Net lending & 15.4 & 7.6 & 5.8 & -0.6 & 0.8 & 1.0 & 1.0 & 1.0 & 1.0 & 1.0 & 1.0 \\
\hline Capital expenditure & 89.7 & 87.9 & 124.0 & 86.3 & 116.7 & 116.7 & 104.8 & 111.0 & 121.2 & 129.4 & 141.7 \\
\hline Current balance & -0.9 & -26.2 & -62.8 & 51.2 & -22.3 & -22.2 & 38.8 & 62.1 & 69.9 & 67.8 & 67.9 \\
\hline Overall balance (before grants) & -106.0 & -121.7 & -192.6 & -33.3 & -139.8 & -139.9 & -67.1 & -49.8 & -52.2 & -62.6 & -74.8 \\
\hline Grants & 28.3 & 67.5 & 50.7 & 68.3 & 80.1 & 80.1 & 44.6 & 17.6 & 17.6 & 17.6 & 17.6 \\
\hline Overall balance (after grants) & -77.7 & -54.2 & -141.9 & 35.0 & -59.7 & -59.7 & -22.4 & -32.3 & -34.7 & -45.0 & -57.3 \\
\hline Primary balance & 51.0 & 68.9 & -14.9 & 160.9 & 68.1 & 67.9 & 93.4 & 82.8 & 85.3 & 86.1 & 82.3 \\
\hline Financing & 106.4 & 115.4 & 172.8 & -42.3 & 8.1 & 15.8 & -16.8 & -37.5 & -95.7 & -88.3 & -27.8 \\
\hline Net foreign financing & 70.3 & 2.9 & 5.0 & 6.4 & -127.1 & -112.9 & -95.5 & -47.4 & -104.6 & -105.8 & -42.8 \\
\hline Disbursements 5/ & 104.3 & 32.2 & 41.9 & 143.3 & 65.5 & 79.1 & 12.9 & 2.1 & 0.0 & 0.0 & 0.0 \\
\hline Amortization & 33.9 & 29.2 & 36.9 & 136.9 & 192.6 & 192.0 & 108.4 & 49.5 & 104.6 & 105.8 & 42.8 \\
\hline Net domestic financing & -49.3 & 57.1 & 136.8 & -88.6 & -106.6 & -106.6 & -6.0 & -6.5 & -7.1 & -65.5 & -9.7 \\
\hline Banking system & -133.9 & 17.1 & 101.7 & -124.6 & -106.6 & -106.6 & -6.0 & -6.5 & -7.1 & -65.5 & -9.7 \\
\hline Nonbanks and other & 45.4 & 22.6 & 11.4 & -2.0 & 0.0 & 0.0 & 0.0 & 0.0 & 0.0 & 0.0 & 0.0 \\
\hline Financing arrangement on fuel purchase & 39.2 & 17.4 & 23.6 & 38.0 & 0.0 & 0.0 & 0.0 & 0.0 & 0.0 & 0.0 & 0.0 \\
\hline Change in arrears & 23.1 & 24.0 & 18.3 & 31.8 & -31.4 & -31.4 & 0.0 & 0.0 & 0.0 & 0.0 & 0.0 \\
\hline External & 0.0 & 0.0 & 0.0 & 63.8 & -31.4 & -31.4 & 0.0 & 0.0 & 0.0 & 0.0 & 0.0 \\
\hline Amortization & 0.0 & 0.0 & 0.0 & 49.1 & -24.2 & -24.2 & 0.0 & 0.0 & 0.0 & 0.0 & 0.0 \\
\hline Interest & 0.0 & 0.0 & 0.0 & 14.7 & -7.2 & -7.2 & 0.0 & 0.0 & 0.0 & 0.0 & 0.0 \\
\hline Domestic & 23.1 & 24.0 & 18.3 & -32.0 & 0.0 & 0.0 & 0.0 & 0.0 & 0.0 & 0.0 & 0.0 \\
\hline Sale/purchase of assets & 62.3 & 31.4 & 12.8 & 8.1 & 3.9 & 3.9 & 4.1 & 8.6 & 9.2 & 66.7 & 10.4 \\
\hline Exceptional financing & & & & & 269.4 & 262.9 & 80.6 & 7.9 & 6.9 & 16.3 & 14.2 \\
\hline Statistical discrepancy & -28.7 & -61.2 & -30.9 & 7.4 & 0.0 & 0.0 & 0.0 & 0.0 & 0.0 & 0.0 & 0.0 \\
\hline Financing gap 6 ; & $\ldots$ & $\ldots$ & $\ldots$ & $\ldots$ & 51.5 & 43.9 & 39.2 & 69.7 & 130.4 & 133.3 & 85.1 \\
\hline \multicolumn{12}{|l|}{ Memorandum items: } \\
\hline GDP (market prices) & 1,998 & 1,859 & 1,818 & 1,932 & 2,009 & 1,992 & 2,082 & 2,203 & 2,345 & 2,505 & 2,675 \\
\hline Public sector debt (end of period) & 2,617 & 2,761 & 2,978 & 2,981 & 2,890 & 2,887 & 2,903 & 2,930 & 2,960 & 2,941 & 2,992 \\
\hline \multicolumn{12}{|l|}{ Of which } \\
\hline Central government & 2,008 & 2,137 & 2,353 & 2,378 & 2,318 & 2,306 & 2,322 & 2,349 & 2,379 & 2,360 & 2,411 \\
\hline Domestic & 1,351 & 1,455 & 1,641 & 1,555 & 1,552 & 1,546 & 1,579 & 1,639 & 1,766 & 1,839 & 1,913 \\
\hline External & 656 & 682 & 711 & 823 & 766 & 760 & 743 & 710 & 613 & 521 & 498 \\
\hline
\end{tabular}

Sources: St. Kitts and Nevis authorities; and Fund staff estimates.

1/ Combined accounts of the Federal Government of St. Kitts and Nevis and the Nevis Island Administration. Reflect the outcome of the debt exchange offer to bondholders and external commercial creditors.

2/ Second review under SBA, EBS 12/61.

3/ The sharp drop in international taxes and concurrent rise in taxes on domestic goods and services reflect the introduction of VAT in Novermber 2010.

4/ Decline in goods and services expenditure from 2012 reflect the corporatization of the Electricity Department from August 2011.

5/ 2012 disbursement includes financing to regularize the external arrears related to fuel purchases.

6/ From 2012 onwards, to be closed by prospective disbursement from the Fund and donors, and restructuring of domestic debt. 
Table 3. St. Kitts and Nevis: Central Government Fiscal Operations, 2008-17 1/

(In percent of GDP)

\begin{tabular}{|c|c|c|c|c|c|c|c|c|c|c|c|}
\hline & \multirow[b]{2}{*}{2008} & \multirow[b]{2}{*}{2009} & \multirow[b]{2}{*}{2010} & \multirow{2}{*}{$\begin{array}{r}\text { Prel. } \\
2011 \\
\end{array}$} & \multirow{2}{*}{$\begin{array}{r}\text { Prog. 2/ } \\
2012 \\
\end{array}$} & \multirow{2}{*}{$\begin{array}{r}\text { Rev. proj. } \\
2012 \\
\end{array}$} & \multicolumn{5}{|c|}{ Proj. } \\
\hline & & & & & & & 2013 & 2014 & 2015 & 2016 & 2017 \\
\hline Total revenue & 27.2 & 29.0 & 28.2 & 33.7 & 26.1 & 26.3 & 27.2 & 27.2 & 27.0 & 26.8 & 26.6 \\
\hline Current revenue & 27.2 & 29.0 & 28.2 & 33.6 & 26.1 & 26.3 & 27.2 & 27.2 & 27.0 & 26.8 & 26.6 \\
\hline Tax revenue & 21.1 & 21.3 & 18.8 & 21.1 & 20.9 & 20.8 & 21.6 & 21.6 & 21.6 & 21.6 & 21.6 \\
\hline Taxes on income & 6.8 & 8.0 & 5.1 & 4.5 & 4.1 & 4.3 & 4.3 & 4.3 & 4.3 & 4.3 & 4.3 \\
\hline Taxes on property & 0.3 & 0.5 & 0.5 & 0.5 & 0.5 & 0.6 & 0.6 & 0.6 & 0.6 & 0.6 & 0.6 \\
\hline Taxes on domestic goods and consumption $3 /$ & 4.2 & 3.7 & 4.6 & 10.8 & 10.8 & 10.8 & 11.1 & 11.1 & 11.1 & 11.1 & 11.1 \\
\hline Taxes on international trade and transactions & 9.8 & 9.1 & 8.6 & 5.4 & 5.5 & 5.2 & 5.6 & 5.6 & 5.6 & 5.6 & 5.6 \\
\hline Nontax revenue & 6.1 & 7.7 & 9.4 & 12.5 & 5.2 & 5.5 & 5.6 & 5.6 & 5.4 & 5.3 & 5.1 \\
\hline Capital revenue & 0.0 & 0.0 & 0.0 & 0.1 & 0.0 & 0.0 & 0.0 & 0.0 & 0.0 & 0.0 & 0.0 \\
\hline Total expenditure and net lending & 32.5 & 35.6 & 38.8 & 35.4 & 33.0 & 33.3 & 30.4 & 29.4 & 29.2 & 29.3 & 29.4 \\
\hline Current expenditure & 27.3 & 30.4 & 31.7 & 31.0 & 27.2 & 27.4 & 25.3 & 24.4 & 24.0 & 24.1 & 24.1 \\
\hline Wages and salaries & 10.2 & 12.6 & 12.3 & 11.5 & 11.2 & 11.3 & 10.8 & 10.5 & 10.3 & 10.3 & 10.3 \\
\hline Goods and services 4/ & 7.6 & 8.1 & 9.3 & 9.3 & 5.4 & 5.5 & 5.3 & 5.1 & 5.1 & 5.1 & 5.1 \\
\hline Interest & 6.4 & 6.6 & 7.0 & 6.5 & 6.4 & 6.4 & 5.6 & 5.2 & 5.1 & 5.2 & 5.2 \\
\hline Domestic & 4.3 & 4.4 & 4.8 & 4.7 & 5.1 & 5.1 & 4.5 & 4.5 & 4.5 & 4.7 & 4.8 \\
\hline Foreign & 2.1 & 2.2 & 2.2 & 1.8 & 1.3 & 1.3 & 1.0 & 0.8 & 0.7 & 0.5 & 0.4 \\
\hline Transfers & 3.0 & 3.2 & 3.1 & 3.7 & 4.2 & 4.3 & 3.7 & 3.6 & 3.5 & 3.5 & 3.5 \\
\hline Net lending & 0.8 & 0.4 & 0.3 & 0.0 & 0.0 & 0.1 & 0.0 & 0.0 & 0.0 & 0.0 & 0.0 \\
\hline Capital expenditure & 4.5 & 4.7 & 6.8 & 4.5 & 5.8 & 5.9 & 5.0 & 5.0 & 5.2 & 5.2 & 5.3 \\
\hline Current balance & 0.0 & -1.4 & -3.5 & 2.7 & -1.1 & -1.1 & 1.9 & 2.8 & 3.0 & 2.7 & 2.5 \\
\hline Overall balance (before grants) & -5.3 & -6.5 & -10.6 & -1.7 & -7.0 & -7.0 & -3.2 & -2.3 & -2.2 & -2.5 & -2.8 \\
\hline Grants & 1.4 & 3.6 & 2.8 & 3.5 & 4.0 & 4.0 & 2.1 & 0.8 & 0.7 & 0.7 & 0.7 \\
\hline Overall balance (after grants) & -3.9 & -2.9 & -7.8 & 1.8 & -3.0 & -3.0 & -1.1 & -1.5 & -1.5 & -1.8 & -2.1 \\
\hline Primary balance & 2.6 & 3.7 & -0.8 & 8.3 & 3.4 & 3.4 & 4.5 & 3.8 & 3.6 & 3.4 & 3.1 \\
\hline Financing & 5.3 & 6.2 & 9.5 & -2.2 & 0.4 & 0.8 & -0.8 & -1.7 & -4.1 & -3.5 & -1.0 \\
\hline Net foreign financing & 3.5 & 0.2 & 0.3 & 0.3 & -6.3 & -5.7 & -4.6 & -2.2 & -4.5 & -4.2 & -1.6 \\
\hline Drawings 5/ & 5.2 & 1.7 & 2.3 & 7.4 & 3.3 & 4.0 & 0.6 & 0.1 & 0.0 & 0.0 & 0.0 \\
\hline Amortization & 1.7 & 1.6 & 2.0 & 7.1 & 9.6 & 9.6 & 5.2 & 2.2 & 4.5 & 4.2 & 1.6 \\
\hline Net domestic financing & -2.5 & 3.1 & 7.5 & -4.6 & -5.3 & -5.4 & -0.3 & -0.3 & -0.3 & -2.6 & -0.4 \\
\hline Banking system & -6.7 & 0.9 & 5.6 & -6.4 & -5.3 & -5.4 & -0.3 & -0.3 & -0.3 & -2.6 & -0.4 \\
\hline Nonbanks and other & 2.3 & 1.2 & 0.6 & -0.1 & 0.0 & 0.0 & 0.0 & 0.0 & 0.0 & 0.0 & 0.0 \\
\hline Financing arrangement on fuel purchase & 2.0 & 0.9 & 1.3 & 2.0 & 0.0 & 0.0 & 0.0 & 0.0 & 0.0 & 0.0 & 0.0 \\
\hline Change in arrears & 1.2 & 1.3 & 1.0 & 1.6 & -1.6 & -1.6 & 0.0 & 0.0 & 0.0 & 0.0 & 0.0 \\
\hline External & 0.0 & 0.0 & 0.0 & 3.3 & -1.6 & -1.6 & 0.0 & 0.0 & 0.0 & 0.0 & 0.0 \\
\hline Amortization & 0.0 & 0.0 & 0.0 & 2.5 & -1.2 & -1.2 & 0.0 & 0.0 & 0.0 & 0.0 & 0.0 \\
\hline Interest & 0.0 & 0.0 & 0.0 & 0.8 & -0.4 & -0.4 & 0.0 & 0.0 & 0.0 & 0.0 & 0.0 \\
\hline Domestic & 1.2 & 1.3 & 1.0 & -1.7 & 0.0 & 0.0 & 0.0 & 0.0 & 0.0 & 0.0 & 0.0 \\
\hline Sale/purchase of assets & 3.1 & 1.7 & 0.7 & 0.4 & 0.2 & 0.2 & 0.2 & 0.4 & 0.4 & 2.7 & 0.4 \\
\hline Exceptional financing & 0.0 & 0.0 & 0.0 & 0.0 & 13.4 & 13.2 & 3.9 & 0.4 & 0.3 & 0.7 & 0.5 \\
\hline Statistical discrepancy & -1.4 & -3.3 & -1.7 & 0.4 & 0.0 & 0.0 & 0.0 & 0.0 & 0.0 & 0.0 & 0.0 \\
\hline Financing gap 6/ & 0.0 & 0.0 & 0.0 & 0.0 & 2.6 & 2.2 & 1.9 & 3.2 & 5.6 & 5.3 & 3.2 \\
\hline \multicolumn{12}{|l|}{ Memorandum items: } \\
\hline $\begin{array}{l}\text { Public sector debt (end of period) } \\
\text { Of which }\end{array}$ & 131.0 & 148.5 & 163.9 & 154.3 & 143.9 & 144.9 & 139.5 & 133.0 & 126.2 & 117.4 & 111.9 \\
\hline Central government & 100.5 & 114.9 & 129.4 & 123.1 & 115.4 & 115.7 & 111.6 & 106.6 & 101.4 & 94.2 & 90.1 \\
\hline Domestic & 67.6 & 78.3 & 90.3 & 80.5 & 77.3 & 77.6 & 75.8 & 74.4 & 75.3 & 73.4 & 71.5 \\
\hline External & 32.8 & 36.7 & 39.1 & 42.6 & 38.1 & 38.1 & 35.7 & 32.2 & 26.1 & 20.8 & 18.6 \\
\hline
\end{tabular}

Sources: St. Kitts and Nevis authorities; and Fund staff estimates.

$1 /$ Combined accounts of the Federal Government of St. Kitts and Nevis and the Nevis Island Administration. Reflect the outcome of the debt exchange offer to bondholders and external commercial creditors.

$2 /$ Second review under SBA, EBS 12/61.

3/ The sharp drop in international taxes and concurrent rise in taxes on domestic goods and services reflect the introduction of VAT in November 2010.

4/ Decline in goods and services expenditure from 2012 reflect the corporatization of the Electricity Department from August 2011.

5/ 2012 disbursement includes financing to regularize the external arrears related to fuel purchases.

6/ From 2012 onwards, to be closed by prospective disbursement from the Fund and donors, and restructuring of domestic debt. 
Table 4. St Kitts and Nevis: Balance of Payments, 2008-17 ${ }^{1 /}$

\begin{tabular}{|c|c|c|c|c|c|c|c|c|c|c|}
\hline & & & & Prel. & Proj. & & & Proj. & & \\
\hline & 2008 & 2009 & 2010 & 2011 & 2012 & 2013 & 2014 & 2015 & 2016 & 2017 \\
\hline & & & & (In millic & of Easter & Caribbear & ollars) & & & \\
\hline Current account & -486.2 & -507.8 & -401.9 & -293.7 & -339.8 & -342.3 & -355.6 & -365.1 & -379.8 & -398.3 \\
\hline Trade balance & -585.6 & -628.8 & -589.4 & -526.8 & -502.7 & -517.0 & -539.6 & -570.1 & -607.1 & -648.3 \\
\hline Exports, f.o.b. & 186.2 & 101.6 & 105.5 & 147.4 & 155.1 & 163.6 & 174.2 & 185.1 & 199.4 & 215.3 \\
\hline Imports f.o.b. & -771.8 & -730.4 & -694.9 & -674.2 & -657.8 & -680.6 & -713.8 & -755.2 & -806.5 & -863.6 \\
\hline Of which & & & & & & & & & & \\
\hline Mineral fuel & -80.3 & -80.2 & -81.5 & -101.2 & -99.3 & -91.9 & -89.4 & -88.0 & -86.0 & -85.5 \\
\hline Services and transfers (net) & 99.4 & 121.0 & 187.5 & 233.1 & 162.9 & 174.7 & 184.1 & 204.9 & 227.3 & 250.1 \\
\hline Services (net) & 110.7 & 96.4 & 164.1 & 197.5 & 152.2 & 165.6 & 183.6 & 202.7 & 222.9 & 244.3 \\
\hline Services (receipts) & 435.0 & 356.1 & 432.6 & 458.8 & 421.7 & 447.2 & 481.6 & 519.9 & 561.6 & 606.1 \\
\hline Of which & & & & & & & & & & \\
\hline Tourism receipts & 297.2 & 225.4 & 243.1 & 240.7 & 259.4 & 278.2 & 302.8 & 329.2 & 357.5 & 387.7 \\
\hline Services (payments) & -324.3 & -259.7 & -268.5 & -261.3 & -269.5 & -281.6 & -298.0 & -317.2 & -338.8 & -361.8 \\
\hline Factor income (net) & -100.7 & -97.3 & -102.4 & -93.6 & -87.1 & -83.8 & -82.1 & -83.9 & -85.5 & -88.1 \\
\hline Of which & & & & & & & & & & \\
\hline Public sector interest & -55.6 & -53.3 & -50.7 & -40.4 & -32.2 & -26.5 & -21.4 & -19.3 & -16.5 & -14.5 \\
\hline Transfers (net) & 89.4 & 121.9 & 125.8 & 129.2 & 97.8 & 92.9 & 82.6 & 86.1 & 89.9 & 93.9 \\
\hline Official (net) & 12.4 & 41.6 & 34.0 & 37.2 & 18.3 & 10.7 & -2.9 & -2.9 & -2.9 & -2.9 \\
\hline Private (net) & 77.0 & 80.3 & 91.8 & 92.0 & 79.4 & 82.3 & 85.5 & 89.0 & 92.8 & 96.8 \\
\hline Capital and financial account & 479.2 & 505.2 & 399.1 & 302.5 & 67.6 & 225.1 & 347.8 & 380.1 & 409.5 & 413.2 \\
\hline Official & 33.5 & -11.9 & 13.9 & 58.4 & -102.1 & -84.4 & -32.0 & -36.9 & -37.9 & -22.4 \\
\hline Capital transfers (net) & 49.1 & 11.9 & 37.1 & 31.0 & 50.1 & 22.3 & 8.8 & 8.8 & 8.8 & 8.8 \\
\hline Long-term borrowing (net) & -15.5 & -23.8 & -23.2 & 27.4 & -152.2 & -106.7 & -40.8 & -45.6 & -46.7 & -31.2 \\
\hline Disbursements & 45.7 & 32.3 & 42.2 & 122.8 & 62.7 & 19.4 & 11.5 & 3.3 & 3.4 & 12.4 \\
\hline Amortization & -61.3 & -56.1 & -65.4 & -95.3 & -116.1 & -126.1 & -52.3 & -48.9 & -50.1 & -43.6 \\
\hline Debt forgiveness & $\ldots$ & $\ldots$ & $\ldots$ & $\ldots$ & -98.8 & 0.0 & 0.0 & 0.0 & 0.0 & 0.0 \\
\hline Private capital & 445.6 & 517.2 & 385.2 & 244.1 & 169.7 & 309.5 & 379.8 & 417.0 & 447.4 & 435.6 \\
\hline Capital transfers (net) & 11.1 & 11.9 & 12.2 & 12.3 & 12.4 & 12.3 & 12.2 & 12.0 & 11.8 & 11.6 \\
\hline Foreign direct investment (net) & 480.3 & 353.0 & 361.2 & 308.0 & 264.7 & 325.8 & 387.6 & 436.5 & 468.5 & 480.0 \\
\hline Portfolio investment (net) & 28.3 & -30.1 & -40.2 & -33.0 & -35.0 & -20.0 & -20.0 & -20.0 & -20.0 & -20.0 \\
\hline Short-term capital (net) & -149.6 & 173.5 & 54.7 & -90.0 & -65.0 & -20.0 & -20.0 & -25.0 & -30.0 & -30.0 \\
\hline Other private (net) & 75.5 & 8.9 & -2.8 & 46.9 & -7.3 & 11.4 & 20.0 & 13.5 & 17.1 & -6.0 \\
\hline Errors and omissions & 23.3 & 12.8 & 72.9 & 0.0 & 0.0 & 0.0 & 0.0 & 0.0 & 0.0 & 0.0 \\
\hline Overall balance & 16.3 & 10.3 & 70.1 & 8.8 & -272.2 & -117.2 & -7.8 & 15.0 & 29.6 & 14.9 \\
\hline Financing & -16.3 & -10.3 & -70.1 & -8.8 & 272.2 & 117.2 & 7.8 & -15.0 & -29.6 & -14.9 \\
\hline Net international reserves & -39.4 & -34.3 & -88.4 & -108.9 & 2.3 & 0.1 & -3.5 & -2.9 & -2.8 & -3.2 \\
\hline Change in arrears & 23.1 & 24.0 & 18.3 & 4.3 & -2.9 & 0.0 & 0.0 & 0.0 & 0.0 & 0.0 \\
\hline Net use of IMF resources & $\ldots$ & $\ldots$ & $\ldots$ & 95.7 & 90.5 & 28.0 & 0.7 & -71.5 & -88.0 & -38.8 \\
\hline Purchase & & & & 95.7 & 90.5 & 28.0 & 12.7 & 0.0 & 0.0 & 0.0 \\
\hline Repurchase & & & & 0.0 & 0.0 & 0.0 & -12.0 & -71.5 & -88.0 & -38.8 \\
\hline Financing gap & $\ldots$ & $\ldots$ & $\ldots$ & 0.0 & 182.3 & 89.1 & 10.6 & 59.5 & 61.2 & 27.1 \\
\hline Debt forgiveness (flow) 2/ & $\ldots$ & $\ldots$ & $\ldots$ & 0.0 & 63.0 & 75.1 & 2.8 & 1.6 & 8.5 & 4.9 \\
\hline Debt forgiveness (stock write-down) & $\ldots$ & $\ldots$ & $\ldots$ & 0.0 & 98.8 & 0.0 & 0.0 & 0.0 & 0.0 & 0.0 \\
\hline Other & $\ldots$ & $\ldots$ & $\ldots$ & 0.0 & 20.5 & 14.0 & 7.8 & 57.9 & 52.8 & 22.2 \\
\hline & & & & & (In perce & $f(G D P)$ & & & & \\
\hline Current account & -24.3 & -27.3 & -22.1 & -15.2 & -17.1 & -16.4 & -16.1 & -15.6 & -15.2 & -14.9 \\
\hline Exports of goods and nonfactor services & 31.1 & 24.6 & 29.6 & 31.4 & 29.0 & 29.3 & 29.8 & 30.1 & 30.4 & 30.7 \\
\hline Merchandise exports & 9.3 & 5.5 & 5.8 & 7.6 & 7.8 & 7.9 & 7.9 & 7.9 & 8.0 & 8.0 \\
\hline Nonfactor services & 21.8 & 19.1 & 23.8 & 23.7 & 21.2 & 21.5 & 21.9 & 22.2 & 22.4 & 22.7 \\
\hline Of which & & & & & & & & & & \\
\hline Tourism receipts & 14.9 & 12.1 & 13.4 & 12.5 & 13.0 & 13.4 & 13.7 & 14.0 & 14.3 & 14.5 \\
\hline Imports of goods and nonfactor services & -54.8 & -53.2 & -53.0 & -48.4 & -46.5 & -46.2 & -45.9 & -45.7 & -45.7 & -45.8 \\
\hline Merchandise imports & -38.6 & -39.3 & -38.2 & -34.9 & -33.0 & -32.7 & -32.4 & -32.2 & -32.2 & -32.3 \\
\hline Nonfactor services & -16.2 & -14.0 & -14.8 & -13.5 & -13.5 & -13.5 & -13.5 & -13.5 & -13.5 & -13.5 \\
\hline Foreign direct investment (net) & 24.0 & 19.0 & 19.9 & 15.9 & 13.3 & 15.7 & 17.6 & 18.6 & 18.7 & 17.9 \\
\hline Stock of unpaid fuel expenses & 1.2 & 2.5 & 2.3 & 0.1 & 0.0 & 0.0 & 0.0 & 0.0 & 0.0 & 0.0 \\
\hline External financing gap & $\ldots$ & $\ldots$ & $\ldots$ & 0.0 & 1.0 & 0.7 & 0.4 & 2.5 & 2.1 & 0.8 \\
\hline External public debt & 44.6 & 48.1 & 49.5 & 50.7 & 45.5 & 42.1 & 37.7 & 30.7 & 24.7 & 21.9 \\
\hline & & & & & nual perce & ge chans & & & & \\
\hline Merchandise exports & 19.5 & -45.4 & 3.9 & 39.6 & 5.3 & 5.5 & 6.5 & 6.3 & 7.7 & 8.0 \\
\hline Tourism receipts & -11.8 & -24.1 & 7.8 & -1.0 & 7.8 & 7.2 & 8.8 & 8.7 & 8.6 & 8.4 \\
\hline Merchandise imports & 19.3 & -5.4 & -4.9 & -3.0 & -2.4 & 3.5 & 4.9 & 5.8 & 6.8 & 7.1 \\
\hline Terms of trade & -2.4 & 3.4 & -3.9 & -2.7 & 1.1 & 0.5 & 0.8 & 0.9 & 0.5 & 0.3 \\
\hline & & & (In & cent of $e$ & orts of go & s and no & ctor servi & & & \\
\hline External public debt & 143.4 & 195.5 & 167.2 & 161.5 & 157.2 & 143.3 & 126.5 & 102.2 & 81.1 & 71.2 \\
\hline $\begin{array}{l}\text { External debt service } \\
\text { Of which }\end{array}$ & 18.8 & 23.9 & 21.6 & 22.4 & 25.7 & 25.0 & 13.1 & 19.6 & 17.6 & 8.2 \\
\hline $\begin{array}{l}\text { Interest } \\
\text { Inten }\end{array}$ & 8.6 & 11.0 & 9.1 & 6.4 & 5.4 & 4.2 & 3.2 & 2.6 & 2.1 & 1.7 \\
\hline & & & & & Millions o & S dollar) & & & & \\
\hline ECCB imputed reserves & 110.2 & 122.9 & 155.7 & 196.0 & 194.3 & 192.5 & 192.8 & 193.9 & 195.0 & 196.2 \\
\hline
\end{tabular}

Sources: ECCB; and Fund staff estimates and projections.

$1 /$ Reflect the outcome of the debt exchange offer to bondholders and external commercial creditors.

$2 /$ The NPV of consolidated amounts under the debt service reduction option was reduced by 6.6 percent. 
Table 5. St. Kitts and Nevis: Monetary Survey , 2008-13

\begin{tabular}{|c|c|c|c|c|c|c|}
\hline & 2008 & 2009 & 2010 & $\begin{array}{r}\text { Prel. } \\
2011\end{array}$ & $\begin{array}{r}\text { Proj. } \\
2012\end{array}$ & $\begin{array}{r}\text { Proj. } \\
2013\end{array}$ \\
\hline \multicolumn{7}{|c|}{ (In millions of EC\$) } \\
\hline Net foreign assets & 850.7 & 711.5 & 730.1 & 929.0 & 989.4 & 1004.5 \\
\hline ECCB imputed reserves & 297.6 & 331.9 & 420.3 & 529.2 & 524.5 & 519.6 \\
\hline Crown agents & 10.6 & 10.6 & 10.6 & 10.6 & 10.6 & 10.6 \\
\hline Commercial banks & 542.4 & 369.0 & 299.2 & 389.3 & 454.3 & 474.3 \\
\hline Net domestic assets & 799.8 & 1036.4 & 1172.6 & 1163.2 & 1168.3 & 1250.3 \\
\hline Net credit to the public sector & 366.3 & 390.9 & 476.4 & 305.7 & 279.0 & 267.5 \\
\hline Net credit to central government & 337.2 & 427.4 & 850.8 & 726.2 & 726.2 & 726.2 \\
\hline Net credit to St. Kitts & 263.0 & 298.9 & 676.6 & 521.4 & 521.4 & 521.4 \\
\hline Net credit to Nevis & 74.2 & 128.5 & 174.3 & 204.8 & 204.8 & 204.8 \\
\hline Net credit to non-financial public sector & 29.1 & -36.5 & -374.5 & -420.5 & -447.2 & -458.7 \\
\hline Credit to the private sector $1 /$ & 1242.7 & 1311.1 & 1356.6 & 1406.4 & 1438.2 & 1531.6 \\
\hline Net other assets $2 /$ & -809.2 & -665.6 & -660.4 & -548.9 & -548.9 & -548.9 \\
\hline Broad money (M2) & 1650.5 & 1747.9 & 1902.7 & 2092.3 & 2157.7 & 2254.8 \\
\hline Money & 251.7 & 243.9 & 349.0 & 470.2 & 484.9 & 506.8 \\
\hline Currency in circulation & 70.1 & 78.3 & 101.1 & 102.0 & 105.2 & 109.9 \\
\hline Demand deposits 1/ & 181.6 & 165.5 & 248.0 & 368.2 & 379.8 & 396.8 \\
\hline Quasi-money 1/ & 1398.8 & 1504.0 & 1553.7 & 1622.0 & 1672.8 & 1748.0 \\
\hline Savings deposits & 602.6 & 638.5 & 638.4 & 684.8 & 706.2 & 738.0 \\
\hline Time deposits & 398.1 & 491.0 & 552.4 & 581.3 & 599.5 & 626.4 \\
\hline Foreign currency deposits & 398.1 & 374.5 & 362.8 & 356.0 & 367.1 & 383.6 \\
\hline \multicolumn{7}{|c|}{ (Percentage change relative to broad money at beginning of period) } \\
\hline Net foreign assets & 11.6 & -8.4 & 1.1 & 10.5 & 2.9 & 0.7 \\
\hline Net domestic assets & -10.0 & 14.3 & 7.8 & -0.5 & 0.2 & 3.8 \\
\hline Net credit to the public sector & -1.7 & 1.5 & 4.9 & -9.0 & -1.3 & -0.5 \\
\hline Net credit to central government & -7.9 & 5.5 & 24.2 & -6.5 & 0.0 & 0.0 \\
\hline Net credit to non-financial public sector & 6.2 & -4.0 & -19.3 & -2.4 & -1.3 & -0.5 \\
\hline Credit to the private sector 1 / & 4.3 & 4.1 & 2.6 & 2.6 & 1.5 & 4.3 \\
\hline Net other assets 2/ & -12.6 & 8.7 & 0.3 & 5.9 & 0.0 & 0.0 \\
\hline \multicolumn{7}{|c|}{ (Annual percentage change) } \\
\hline Broad money (M2) & 1.6 & 5.9 & 8.9 & 10.0 & 3.1 & 4.5 \\
\hline Money & 11.4 & -3.1 & 43.1 & 34.7 & 3.1 & 4.5 \\
\hline Currency in circulation & 24.8 & 11.7 & 29.0 & 0.9 & 3.1 & 4.5 \\
\hline Demand deposits $1 /$ & 6.9 & -8.8 & 49.8 & 48.5 & 3.1 & 4.5 \\
\hline Quasi-money 1/ & 0.0 & 7.5 & 3.3 & 4.4 & 3.1 & 4.5 \\
\hline Savings deposits & 6.5 & 6.0 & 0.0 & 7.3 & 3.1 & 4.5 \\
\hline Time deposits & 5.4 & 23.3 & 12.5 & 5.2 & 3.1 & 4.5 \\
\hline Foreign currency deposits & -12.6 & -5.9 & -3.1 & -1.9 & 3.1 & 4.5 \\
\hline Credit to the private sector (in nominal terms) & 5.9 & 5.5 & 3.5 & 3.7 & 2.3 & 6.5 \\
\hline Credit to the private sector (in real terms) & 1.4 & 4.3 & -1.6 & 0.8 & 0.4 & 3.9 \\
\hline \multicolumn{7}{|l|}{ Memorandum items: } \\
\hline Income velocity of money & 7.9 & 7.6 & 5.2 & 4.1 & 4.1 & 4.1 \\
\hline Income velocity of broad money & 1.2 & 1.1 & 1.0 & 0.9 & 0.9 & 0.9 \\
\hline Private sector credit/GDP (in percent) & 62.2 & 70.5 & 74.6 & 72.8 & 72.2 & 73.6 \\
\hline Foreign currency deposits/GDP (in percent) & 19.9 & 20.1 & 20.0 & 18.4 & 18.4 & 18.4 \\
\hline
\end{tabular}

Sources: ECCB; and Fund staff estimates and projections.

1/ Data up to 2008 is revised to reflect the changes in the definition of private sector in January 2009.

2/ Includes capital accounts. 
Table 6. St. Kitts and Nevis: Indicators of External and Financial Vulnerability, 2006-12

(12-month percentage change, unless otherwise stated)

\begin{tabular}{|c|c|c|c|c|c|c|c|}
\hline & 2006 & 2007 & 2008 & 2009 & 2010 & 2011 & $\begin{array}{r}\text { Proj. } \\
2012 \\
\end{array}$ \\
\hline \multicolumn{8}{|l|}{ External indicators } \\
\hline Merchandise exports & -8.2 & -1.0 & 19.5 & -45.4 & 3.9 & 39.6 & 5.3 \\
\hline Merchandise imports & 18.6 & 9.1 & 19.3 & -5.4 & -4.9 & -3.0 & -2.4 \\
\hline Terms of trade deterioration (-) & -3.8 & -1.5 & -2.4 & 3.4 & -3.9 & -2.7 & 1.1 \\
\hline Tourism earnings & 8.7 & -5.2 & -11.8 & -24.1 & 7.8 & -1.0 & 7.8 \\
\hline Current account balance (percent of GDP) & -14.1 & -16.7 & -24.3 & -27.3 & -22.1 & -15.2 & -17.1 \\
\hline $\begin{array}{l}\text { Capital and financial account balance (percent of GDP) 1/ } \\
\text { Of which }\end{array}$ & 13.8 & 14.6 & 24.0 & 27.2 & 22.0 & 15.7 & 3.4 \\
\hline Foreign direct investment & 17.5 & 19.5 & 24.0 & 19.0 & 19.9 & 15.9 & 13.3 \\
\hline \multicolumn{8}{|l|}{ Gross international reserves of the ECCB } \\
\hline In millions of U.S. dollars & 696.0 & 764.5 & 759.0 & 800.8 & 926.1 & 1007.3 & 989.5 \\
\hline In percent of broad money & 18.6 & 18.6 & 17.0 & 17.5 & 19.7 & 21.2 & 20.2 \\
\hline Commercial banks' net foreign assets (millions of U. S. dollars) & 115.7 & 145.5 & 200.9 & 136.7 & 110.8 & 144.2 & 168.2 \\
\hline External public debt (percent of GDP) & 50.4 & 41.9 & 44.6 & 48.1 & 49.5 & 50.7 & 45.5 \\
\hline $\begin{array}{l}\text { External debt service (in percent of exports of goods and services) } \\
\text { Of which }\end{array}$ & 22.7 & 21.0 & 18.8 & 23.9 & 21.6 & 22.4 & 25.7 \\
\hline Interest & 8.8 & 7.9 & 8.6 & 11.0 & 9.1 & 6.4 & 5.4 \\
\hline Nominal exchange rate (E.C. dollars per U.S. dollar, end period) & 2.7 & 2.7 & 2.7 & 2.7 & 2.7 & 2.7 & 2.7 \\
\hline Real effective exchange rate depreciation (-), end period 2/ & 2.2 & -5.5 & 12.8 & -3.8 & 1.6 & $\cdots$ & $\cdots$ \\
\hline \multicolumn{8}{|l|}{ Financial indicators $3 /$} \\
\hline Broad money & 13.6 & 11.9 & 1.6 & 5.9 & 8.9 & 10.0 & 3.1 \\
\hline Credit to the private sector & 11.5 & 11.9 & 5.9 & 5.5 & 3.5 & 3.7 & 2.3 \\
\hline Share of nonperforming assets to total assets of banks (percent) & 4.8 & 4.1 & 4.5 & 4.3 & 5.5 & 6.6 & 6.6 \\
\hline Provisions for loan losses/nonperforming assets (percent) & 24.3 & 23.9 & 20.0 & 48.9 & 42.2 & 38.3 & 46.6 \\
\hline Provisions for loan losses/total loans (percent) & 1.2 & 1.0 & 0.9 & 2.1 & 2.3 & 2.5 & 3.1 \\
\hline Gross government exposure/total assets (percent) & 31.0 & 29.1 & 28.2 & 26.1 & 26.6 & 24.3 & 23.4 \\
\hline Total loans/total deposits (percent) & 85.1 & 86.9 & 88.7 & 77.4 & 78.1 & 73.0 & 71.7 \\
\hline Net liquid assets/total deposits (percent) & 38.4 & 37.9 & 42.5 & 42.9 & 41.6 & 44.2 & 45.4 \\
\hline Foreign currency deposits/total deposits (percent) & 25.0 & 23.4 & 22.9 & 30.2 & 27.5 & 25.6 & 26.2 \\
\hline Liquid assets/total asset (percent) & 39.9 & 38.0 & 39.5 & 43.7 & 41.9 & 44.2 & 45.8 \\
\hline Liquid assets/current liabilities (percent) & 45.3 & 47.5 & 48.4 & 50.9 & 51.5 & 51.8 & $\ldots$ \\
\hline Total capital/total assets (percent) 4/ & 13.0 & 15.0 & 16.8 & 19.3 & 18.4 & 16.3 & 15.6 \\
\hline Total Capital/Risk Weighted Assets (percent) 4/ & 39.8 & 43.8 & 42.7 & 47.6 & 42.4 & 40.7 & 40.5 \\
\hline Tier 1 Capital/Risk Weighted Assets (percent) 4/ & 36.0 & 37.7 & 40.1 & 42.0 & 36.8 & 40.1 & 38.9 \\
\hline Ratio of bank's before-tax profits to average assets (percent) & 3.4 & 4.0 & 4.7 & 2.1 & 1.1 & 1.4 & $\ldots$ \\
\hline
\end{tabular}

Sources: ECCB; Ministry of Finance; and Fund staff estimates.

1 / Includes errors and omissions.

2/ Estimated on the basis of weights given by the average trade share during 1999-2003.

3 / For locally incorporated banks only.

4/ 2012 data as of end-March. 
Table 7. St. Kitts and Nevis: External Financing Requirement and Sources, 2011-17 (In millions of U.S. dollars)

\begin{tabular}{|c|c|c|c|c|c|c|c|}
\hline & \multirow{2}{*}{$\begin{array}{l}\text { Prel. } \\
2011\end{array}$} & \multirow{2}{*}{$\begin{array}{r}\text { Program } \\
2012\end{array}$} & \multicolumn{5}{|c|}{ Projection } \\
\hline & & & 2013 & 2014 & 2015 & 2016 & 2017 \\
\hline Gross financing requirement & 199.8 & 230.8 & 175.1 & 150.6 & 157.1 & 164.5 & 178.0 \\
\hline Current account deficit & 108.2 & 125.3 & 125.2 & 130.0 & 133.7 & 140.1 & 147.3 \\
\hline Amortization & 51.3 & 106.4 & 49.9 & 19.4 & 22.4 & 23.3 & 29.5 \\
\hline Official (public sector and central government) & 35.3 & 79.6 & 46.7 & 19.4 & 18.1 & 18.5 & 16.2 \\
\hline of which, debt forgiveness & $\ldots$ & 36.6 & 0.0 & 0.0 & 0.0 & 0.0 & 0.0 \\
\hline Private sector (net) & 16.0 & 26.8 & 3.2 & 0.0 & 4.3 & 4.8 & 13.3 \\
\hline Commercial banks & 33.3 & 24.1 & 7.4 & 7.4 & 9.3 & 11.1 & 11.1 \\
\hline Other private & -17.4 & 2.7 & -4.2 & -7.4 & -5.0 & -6.3 & 2.2 \\
\hline Reserve accumulation (+: increase) & 40.3 & -0.8 & 0.0 & 1.3 & 1.1 & 1.0 & 1.2 \\
\hline Sources of financing & 163.3 & 131.4 & 133.3 & 148.2 & 163.2 & 175.0 & 182.5 \\
\hline Capital grants and transfers & 16.1 & 23.2 & 12.8 & 7.8 & 7.7 & 7.6 & 7.5 \\
\hline Foreign Direct Investment (net) & 114.1 & 98.0 & 120.7 & 143.6 & 161.7 & 173.5 & 177.8 \\
\hline Net inflow of equity and other capital & -12.2 & -13.0 & -7.4 & -7.4 & -7.4 & -7.4 & -7.4 \\
\hline New borrowing & 45.5 & 23.2 & 7.2 & 4.3 & 1.2 & 1.2 & 4.6 \\
\hline of which: public sector & 45.5 & 23.2 & 7.2 & 4.3 & 1.2 & 1.2 & 4.6 \\
\hline Errors and omissions & 0.0 & 0.0 & 0.0 & 0.0 & 0.0 & 0.0 & 0.0 \\
\hline Accumulation of arrears & 1.6 & -1.1 & 0.0 & 0.0 & 0.0 & 0.0 & 0.0 \\
\hline Exceptional external financing & 35.0 & 92.9 & 36.6 & -0.4 & -27.5 & -30.0 & -12.7 \\
\hline IMF net disbursement & 35.0 & 32.9 & 8.8 & -1.5 & -28.1 & -33.2 & -14.5 \\
\hline Fund disbursement & 35.4 & 33.5 & 10.4 & 4.7 & 0.0 & 0.0 & 0.0 \\
\hline Repurchases & 0.0 & 0.0 & 0.0 & -4.4 & -26.5 & -32.6 & -14.4 \\
\hline Interest due & -0.5 & -0.6 & -1.5 & -1.7 & -1.6 & -0.5 & -0.2 \\
\hline Debt forgiveness $1 /$ & 0.0 & 59.9 & 27.8 & 1.0 & 0.6 & 3.1 & 1.8 \\
\hline Other residual & 0.0 & 7.6 & 5.2 & 2.9 & 21.4 & 19.6 & 8.2 \\
\hline
\end{tabular}

1/ Includes flow and stock write-down.

Sources: St. Kitts and Nevis authorities; Eastern Caribbean Central Bank; and Fund staff estimates and projections. 
Table 8: St.Kitts and Nevis: Indicators of Capacity to Repay the Fund, 2012-21

\begin{tabular}{|c|c|c|c|c|c|c|c|c|c|c|}
\hline & 2012 & 2013 & 2014 & 2015 & 2016 & 2017 & 2018 & 2019 & 2020 & 2021 \\
\hline \multicolumn{11}{|l|}{ Fund obligations based on existing credit } \\
\hline (in millions of SDRs) & 0.78 & 1.54 & 3.75 & 16.50 & 15.75 & 2.23 & 0.00 & 0.00 & 0.00 & 0.00 \\
\hline Principal & 0.56 & 1.11 & 3.33 & 16.17 & 15.62 & 2.22 & 0.00 & 0.00 & 0.00 & 0.00 \\
\hline Charges and interest & 0.22 & 0.43 & 0.42 & 0.33 & 0.13 & 0.01 & 0.00 & 0.00 & 0.00 & 0.00 \\
\hline \multicolumn{11}{|l|}{ Fund obligations based on existing and prospective credit } \\
\hline (in millions of SDRs) & 0.93 & 2.07 & 4.41 & 17.54 & 20.72 & 9.08 & 3.13 & 0.71 & 0.00 & 0.00 \\
\hline Principal & 0.56 & 1.11 & 3.33 & 16.56 & 20.38 & 8.98 & 3.10 & 0.71 & 0.00 & 0.00 \\
\hline Charges and interest & 0.37 & 0.96 & 1.08 & 0.98 & 0.34 & 0.10 & 0.03 & 0.00 & 0.00 & 0.00 \\
\hline \multicolumn{11}{|l|}{ Fund credit outstanding based on existing and prospective credit } \\
\hline (in millions of SDRs) & 44.8 & 50.1 & 49.7 & 33.2 & 12.8 & 3.8 & 0.7 & 0.0 & 0.0 & 0.0 \\
\hline \multicolumn{11}{|l|}{ Total Obligations based on existing and prospective credit } \\
\hline in millions of U.S. dollars $1 /$ & 1.5 & 3.3 & 7.1 & 28.1 & 33.2 & 14.5 & 5.0 & 1.1 & 0.0 & 0.0 \\
\hline in percent of exports of goods and services & 0.7 & 1.5 & 2.9 & 10.7 & 11.8 & 4.8 & 1.6 & 0.3 & 0.0 & 0.0 \\
\hline in percent of external debt service $2 /$ & 2.6 & 5.5 & 18.2 & 35.4 & 40.0 & 36.7 & 19.2 & 5.1 & 0.0 & 0.0 \\
\hline in percent of GDP & 0.2 & 0.4 & 0.9 & 3.2 & 3.6 & 1.5 & 0.5 & 0.1 & 0.0 & 0.0 \\
\hline in percent of quota & 10.4 & 23.3 & 49.6 & 197.1 & 232.8 & 102.0 & 35.2 & 8.0 & 0.0 & 0.0 \\
\hline in percent of net imputed reserves & 0.8 & 1.7 & 3.7 & 14.5 & 17.0 & 7.4 & 2.6 & 0.6 & 0.0 & 0.0 \\
\hline in percent of revenue and grants & 0.7 & 1.5 & 3.1 & 11.6 & 13.0 & 5.4 & 1.8 & 0.4 & 0.0 & 0.0 \\
\hline \multicolumn{11}{|l|}{ Outstanding Fund Credit } \\
\hline in millions of U.S. dollars $1 /$ & 71.6 & 80.2 & 79.6 & 53.1 & 20.5 & 6.1 & 1.1 & 0.0 & 0.0 & 0.0 \\
\hline in percent of exports of goods and services & 33.5 & 35.5 & 32.8 & 20.3 & 7.3 & 2.0 & 0.4 & 0.0 & 0.0 & 0.0 \\
\hline in percent of external debt service $2 /$ & 130.4 & 141.9 & 250.7 & 103.9 & 41.3 & 24.3 & 5.4 & 0.0 & 0.0 & 0.0 \\
\hline in number of months of imports of goods and services & 2.5 & 2.7 & 2.5 & 1.6 & 0.6 & 0.2 & 0.0 & 0.0 & 0.0 & 0.0 \\
\hline in percent of GDP & 9.7 & 10.4 & 9.8 & 6.1 & 2.2 & 0.6 & 0.1 & 0.0 & 0.0 & 0.0 \\
\hline in percent of quota & 503.0 & 563.4 & 558.9 & 372.8 & 143.8 & 42.8 & 8.0 & 0.0 & 0.0 & 0.0 \\
\hline in percent of net imputed reserves & 36.9 & 41.7 & 41.3 & 27.4 & 10.5 & 3.1 & 0.6 & 0.0 & 0.0 & 0.0 \\
\hline Net use of Fund Credit (in millions of SDRs) & 20.4 & 5.4 & -0.4 & -16.6 & -20.4 & -9.0 & -3.1 & -0.7 & 0.0 & 0.0 \\
\hline Disbursements & 21.0 & 6.5 & 2.9 & 0.0 & 0.0 & 0.0 & 0.0 & 0.0 & 0.0 & 0.0 \\
\hline Repayment and Repurchases & 0.6 & 1.1 & 3.3 & 16.6 & 20.4 & 9.0 & 3.1 & 0.7 & 0.0 & 0.0 \\
\hline \multicolumn{11}{|l|}{ Memorandum items: } \\
\hline Nominal GDP (in millions of US dollars) & 737.8 & 771.0 & 815.9 & 868.6 & 927.6 & 990.6 & $1,057.8$ & $1,129.7$ & $1,206.4$ & $1,288.3$ \\
\hline Exports of goods and services (in millions of US dollars) & 213.6 & 226.2 & 242.9 & 261.1 & 281.9 & 304.2 & 322.2 & 341.6 & 361.8 & 383.4 \\
\hline External debt service (in millions of US dollars) & 54.9 & 56.5 & 31.8 & 51.1 & 49.6 & 25.1 & 21.1 & 21.3 & 19.0 & 17.4 \\
\hline Imports of goods and services (in millions of US dollars) & 343.4 & 356.4 & 374.7 & 397.2 & 424.2 & 453.8 & 476.5 & 500.4 & 525.5 & 551.9 \\
\hline Net imputed reserves (in millions of US dollars) & 194.3 & 192.5 & 192.8 & 193.9 & 195.0 & 196.2 & 196.2 & 196.2 & 196.2 & 196.2 \\
\hline
\end{tabular}

$1 /$ US $\$ 1=0.625$ SDR (program exchange rate in TMU)

2/Including prospective repurchases/repayments 
Table 9. St. Kitts and Nevis: External Debt Sustainability Framework, 2007-17

(In percent of GDP, unless otherwise indicated)

\begin{tabular}{|c|c|c|c|c|c|c|c|c|c|c|c|c|c|c|}
\hline & \multicolumn{5}{|c|}{ Actual } & & & \multicolumn{7}{|c|}{ Projections } \\
\hline & 2007 & 2008 & 2009 & 2010 & 2011 & & & 2012 & 2013 & 2014 & 2015 & 2016 & 2017 & Debt-stabilizing \\
\hline Baseline: External debt & 41.9 & 44.6 & 48.1 & 49.5 & 50.7 & & & 45.5 & 42.1 & 37.7 & 30.7 & 24.7 & 21.9 & -18.4 \\
\hline Change in external debt & -8.4 & 2.6 & 3.5 & 1.4 & 1.2 & & & -5.1 & -3.5 & -4.4 & -6.9 & -6.1 & -2.8 & \\
\hline Identified external debt-creating flows $(4+8+9)$ & -6.4 & -3.7 & 12.6 & 5.7 & -0.5 & & & 5.2 & 1.0 & -1.6 & -3.3 & -3.8 & -3.1 & \\
\hline Current account deficit, excluding interest payments & 13.9 & 21.5 & 24.4 & 19.3 & 13.1 & & & 15.6 & 15.3 & 15.2 & 14.8 & 14.5 & 14.8 & \\
\hline Deficit in balance of goods and services & 16.0 & 23.8 & 28.6 & 23.4 & 17.0 & & & 17.6 & 16.9 & 16.2 & 15.7 & 15.3 & 15.1 & \\
\hline Exports & 33.5 & 31.1 & 24.6 & 29.6 & 31.4 & & & 29.0 & 29.3 & 29.8 & 30.1 & 30.4 & 30.7 & \\
\hline Imports & 49.5 & 54.8 & 53.2 & 53.0 & 48.4 & & & 46.5 & 46.2 & 45.9 & 45.7 & 45.7 & 45.8 & \\
\hline Net non-debt creating capital inflows (negative) & -17.6 & -25.5 & -17.4 & -17.7 & -14.2 & & & -11.5 & -14.7 & -16.7 & -17.8 & -17.9 & -17.2 & \\
\hline Automatic debt dynamics $2 /$ & -2.6 & 0.2 & 5.5 & 4.0 & 0.6 & & & 1.1 & 0.4 & -0.1 & -0.4 & -0.4 & -0.7 & \\
\hline Contribution from nominal interest rate & 2.8 & 2.8 & 2.8 & 2.8 & 2.2 & & & 1.1 & 1.2 & 1.1 & 1.0 & 0.8 & 0.2 & \\
\hline Contribution from real GDP growth & -2.3 & -1.6 & 2.6 & 1.3 & 1.0 & & & 0.0 & -0.8 & -1.3 & -1.4 & -1.2 & -1.0 & \\
\hline Contribution from price and exchange rate changes $3 /$ & -3.1 & -1.0 & 0.0 & -0.1 & -2.5 & & & $\ldots$ & ... & ... & $\ldots$ & $\ldots$ & $\ldots$ & \\
\hline Residual, incl. change in gross foreign assets (2-3) 4/ & -2.1 & 6.4 & -9.0 & -4.3 & 1.7 & & & -10.3 & -4.5 & -2.8 & -3.6 & -2.2 & 0.4 & \\
\hline External debt-to-exports ratio (in percent) & 125.3 & 143.4 & 195.5 & 167.2 & 161.5 & & & 157.2 & 143.3 & 126.5 & 102.2 & 81.1 & 71.2 & \\
\hline Gross external financing need (in billions of US dollars) 5/ & 0.2 & 0.2 & 0.2 & 0.2 & 0.2 & & & 0.3 & 0.2 & 0.2 & 0.2 & 0.2 & 0.2 & \\
\hline in percent of GDP & 25.5 & 31.3 & 35.1 & 30.6 & 24.6 & 10 -Year & 10 -Year & 35.1 & 23.5 & 23.1 & 24.3 & 22.6 & 19.1 & \\
\hline Scenario with key variables at their historical averages 6 / & & & & & & & & 45.5 & 42.6 & 41.3 & 38.9 & 37.6 & 39.0 & -17.0 \\
\hline & & & & & & Historical & Standard & & & & & & & \\
\hline Key Macroeconomic Assumptions Underlying Baseline & & & & & & Average & Deviation & & & & & & & \\
\hline Real GDP growth (in percent) & 5.0 & 4.0 & -5.6 & -2.7 & -2.0 & 1.3 & 4.6 & 0.0 & 1.8 & 3.2 & 3.8 & 4.2 & 4.2 & \\
\hline GDP deflator in US dollars (change in percent) & 6.6 & 2.5 & -0.1 & 0.2 & 5.3 & 2.9 & 4.3 & 2.5 & 2.5 & 2.5 & 2.5 & 2.5 & 2.5 & \\
\hline Nominal external interest rate (in percent) & 6.1 & 7.1 & 6.0 & 5.7 & 4.5 & 6.4 & 0.9 & 2.3 & 2.8 & 2.9 & 2.8 & 2.7 & 1.0 & \\
\hline Growth of exports (US dollar terms, in percent) & -2.1 & -0.3 & -26.3 & 17.6 & 12.6 & 4.8 & 13.5 & -4.8 & 5.9 & 7.4 & 7.5 & 7.9 & 7.9 & \\
\hline Growth of imports (US dollar terms, in percent) & 6.4 & 19.0 & -9.7 & -2.7 & -2.9 & 4.1 & 9.9 & -0.9 & 3.8 & 5.2 & 6.0 & 6.8 & 7.0 & \\
\hline Current account balance, excluding interest payments & -13.9 & -21.5 & -24.4 & -19.3 & -13.1 & -17.4 & 5.9 & -15.6 & -15.3 & -15.2 & -14.8 & -14.5 & -14.8 & \\
\hline Net non-debt creating capital inflows & 17.6 & 25.5 & 17.4 & 17.7 & 14.2 & 17.8 & 5.9 & 11.5 & 14.7 & 16.7 & 17.8 & 17.9 & 17.2 & \\
\hline
\end{tabular}

$1 /$ Reflect the outcome of the debt exchange offer to bondholders and external commercial creditors.

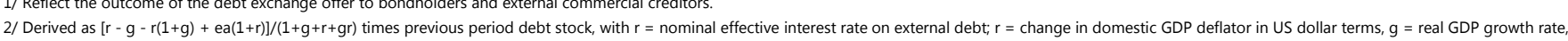

$e=$ nominal appreciation (increase in dollar value of domestic currency), and $a=$ share of domestic-currency denominated debt in total external debt

$3 /$ The contribution from price and exchange rate changes is defined as $[-r(1+g)+$ ea $(1+r)] /(1+g+r+g r)$ times previous period debt stock. r increases with an appreciating domestic currency $(e>0)$ and rising inflation $(b a s e d$ on GDP deflator).

$4 /$ For projection line includes the impact of price and exchange rate changes

5/ Defined as current account deficit, plus amortization on medium- and long-term debt, plus short-term debt at end of previous period.

6/ The key variables include real GDP growth: nominal interest rate; dollar deflator growth; and both non-interest current account and non-debt inflows in percent of GDP.

$7 /$ Long-run, constant balance that stabilizes the debt ratio assuming that key variales (real GDP growth, nominal interest rete, dollar deflator growth and in

of the last projection year. 
Table 10. St. Kitts and Nevis: Public Sector Debt Sustainability Framework, 2007-17 (In percent of GDP, unless otherwise indicated)

\begin{tabular}{|c|c|c|c|c|c|c|c|c|c|c|c|c|}
\hline & \multicolumn{5}{|c|}{ Actual } & \multicolumn{6}{|c|}{ Projections } & \multirow{3}{*}{$\begin{array}{c}\text { Debt-stabilizing } \\
\text { primary } \\
\text { balance } 9 /\end{array}$} \\
\hline & 2007 & 2008 & 2009 & 2010 & 2011 & 2012 & 2013 & 2014 & 2015 & 2016 & 2017 & \\
\hline & & & & & & & & & & & & \\
\hline Baseline: Public sector debt 1/ & 134.0 & 131.0 & 148.5 & 163.9 & 154.3 & 144.9 & 139.5 & 133.0 & 126.2 & 117.4 & 111.9 & -0.9 \\
\hline $\mathrm{o} / \mathrm{w}$ foreign-currency denominated & 41.9 & 44.6 & 48.1 & 49.5 & 50.7 & 44.9 & 41.4 & 37.1 & 30.2 & 24.1 & 21.4 & \\
\hline Change in public sector debt & -11.3 & -3.0 & 17.5 & 15.4 & -9.5 & -9.4 & -5.4 & -6.4 & -6.8 & -8.8 & -5.6 & \\
\hline Identified debt-creating flows $(4+7+12)$ & -13.5 & -7.1 & 9.2 & 11.2 & -6.9 & -0.7 & -5.0 & -6.3 & -6.7 & -8.6 & -5.4 & \\
\hline Primary deficit & -3.3 & -3.2 & -4.6 & -1.5 & -10.4 & -4.3 & -5.9 & -5.4 & -5.2 & -4.8 & -4.5 & \\
\hline Revenue and grants & 36.0 & 35.3 & 39.6 & 38.0 & 44.2 & 37.3 & 36.3 & 34.9 & 34.7 & 34.4 & 34.2 & \\
\hline Primary (noninterest) expenditure & 32.7 & 32.2 & 35.0 & 36.5 & 33.8 & 33.0 & 30.3 & 29.5 & 29.5 & 29.6 & 29.7 & \\
\hline Automatic debt dynamics $2 /$ & -8.3 & -0.8 & 15.4 & 13.4 & 4.0 & 3.8 & 1.1 & -0.6 & -1.1 & -1.1 & -0.5 & \\
\hline Contribution from interest rate/growth differential $3 /$ & -8.3 & -0.8 & 15.4 & 13.4 & 4.0 & 3.8 & 1.1 & -0.6 & -1.1 & -1.1 & -0.5 & \\
\hline Of which contribution from real interest rate & -1.8 & 4.2 & 7.7 & 9.3 & 0.8 & 3.8 & 3.7 & 3.6 & 3.7 & 3.9 & 4.0 & \\
\hline Of which contribution from real GDP growth & -6.5 & -5.1 & 7.8 & 4.1 & 3.2 & 0.0 & -2.6 & -4.2 & -4.8 & -4.9 & -4.6 & \\
\hline Contribution from exchange rate depreciation $4 /$ & 0.0 & 0.0 & 0.0 & 0.0 & 0.0 & ... & $\ldots$ & $\ldots$ & $\ldots$ & $\ldots$ & $\ldots$ & \\
\hline Other identified debt-creating flows & -2.0 & -3.1 & -1.7 & -0.7 & -0.4 & -0.2 & -0.2 & -0.4 & -0.4 & -2.7 & -0.4 & \\
\hline Privatization receipts (negative) & -2.0 & -3.1 & -1.7 & -0.7 & -0.4 & -0.2 & -0.2 & -0.4 & -0.4 & -2.7 & -0.4 & \\
\hline Recognition of implicit or contingent liabilities & 0.0 & 0.0 & 0.0 & 0.0 & 0.0 & 0.0 & 0.0 & 0.0 & 0.0 & 0.0 & 0.0 & \\
\hline Other (specify, e.g. bank recapitalization) & 0.0 & 0.0 & 0.0 & 0.0 & 0.0 & 0.0 & 0.0 & 0.0 & 0.0 & 0.0 & 0.0 & \\
\hline Residual, including asset changes (2-3) 5/ & 2.2 & 4.1 & 8.4 & 4.2 & -2.7 & -8.7 & -0.4 & -0.1 & -0.1 & -0.2 & -0.2 & \\
\hline Public sector debt-to-revenue ratio 1 / & 372.3 & 370.7 & 374.9 & 431.1 & 349.2 & 388.8 & 384.5 & 381.2 & 364.2 & 341.3 & 327.4 & \\
\hline Gross financing need 6 / & 55.5 & 54.3 & 51.1 & 52.2 & 47.9 & 48.5 & 44.0 & 43.3 & 44.6 & 44.2 & 40.9 & \\
\hline in billions of U.S. dollars & 0.4 & 0.4 & 0.4 & 0.4 & 0.3 & 0.4 & 0.3 & 0.4 & 0.4 & 0.4 & 0.4 & \\
\hline Scenario with key variables at their historical averages $7 /$ & & & & & & 144.8 & 146.6 & 148.4 & 150.3 & 149.6 & 151.4 & 2.5 \\
\hline Scenario with no policy change (constant primary balance) in 2012-2017 & & & & & & 144.9 & 141.0 & 135.6 & 129.7 & 121.4 & 116.0 & -0.9 \\
\hline \multicolumn{13}{|l|}{ Key Macroeconomic and Fiscal Assumptions Underlying Baseline } \\
\hline Real GDP growth (in percent) & 5.0 & 4.0 & -5.6 & -2.7 & -2.0 & 0.0 & 1.8 & 3.2 & 3.8 & 4.2 & 4.2 & \\
\hline Average nominal interest rate on public debt (in percent) $8 /$ & 5.5 & 6.0 & 5.5 & 6.3 & 5.7 & 5.0 & 5.2 & 5.4 & 5.6 & 5.9 & 6.3 & \\
\hline Average real interest rate (nominal rate minus change in GDP deflator, in percent) & -1.1 & 3.5 & 5.5 & 6.1 & 0.4 & 2.5 & 2.7 & 2.8 & 3.0 & 3.4 & 3.8 & \\
\hline Nominal appreciation (increase in US dollar value of local currency, in percent) & 0.0 & 0.0 & 0.0 & 0.0 & 0.0 & $\ldots$ & $\ldots$ & $\ldots$ & $\ldots$ & $\ldots$ & $\ldots$ & \\
\hline Inflation rate (GDP deflator, in percent) & 6.6 & 2.5 & -0.1 & 0.2 & 5.3 & 2.5 & 2.5 & 2.5 & 2.5 & 2.5 & 2.5 & \\
\hline Growth of real primary spending (deflated by GDP deflator, in percent) & -3.9 & 3.0 & 1.4 & 1.7 & -6.7 & -1.6 & -6.3 & 0.5 & 3.6 & 4.5 & 4.7 & \\
\hline Primary deficit & -3.3 & -3.2 & -4.6 & -1.5 & -10.4 & -4.3 & -5.9 & -5.4 & -5.2 & -4.8 & -4.5 & \\
\hline
\end{tabular}

1/ Public sector covers general government and gross debt is used. Reflect the outcome of the debt exchange offer to bondholders and external commercial creditors.

$2 /$ Derived as $[(r-p(1+g)-g+a(1+r)](1+g+p+g p))$ times previous period debt ratio, with $r=$ interest rate; $p=$ growth rate of GDP deflator, $g=$ real GDP growth rate; $a=$ share of foreign-currency

$3 /$ The real interest rate contribution is derived from the denominator in footnote $2 /$ as $r-\pi(1+g)$ and the real growth contribution as $-g$

$4 /$ The exchange rate contribution is derived from the numerator in footnote $2 /$ as ae $(1+\mathrm{r})$

line includes exchange rate changes.

$6 /$ Defined as public sector deficit, plus amortization of medium and long-term public sector debt, plus short-term debt at end of previous period.

7/ The key variables include real GDP growth; real interest rate; and primary balance in percent of GDP.

8/Derived as nominal interest expenditure divided by previous period debt stock. 


\section{APPENDIX}

Basseterre, St. Kitts

July 16, 2012

Ms. Christine Lagarde

Managing Director

International Monetary Fund

Washington DC, 20431

Dear Ms. Lagarde:

Since the approval of the Stand-By Arrangement in July 2011, economic activity has contracted in St. Kitts and Nevis, reflecting the challenging global economic conditions. However, with tourism activity registering a marked rebound for January - March 2012 and with a number of major construction projects in the pipeline, the economic decline is expected to bottom out in 2012 with economic activity either being flat or showing a mild recovery. In addition, given our prudent macroeconomic management, we are well positioned to meet our 2012 fiscal targets under the program. This achievement has been possible thanks to the sacrifice and efforts of the people of St. Kitts and Nevis, and with strong support from our commercial creditors, the donor community and international financial institutions, including the Caribbean Development Bank and the IMF.

The Government of St. Kitts and Nevis reaffirms its commitment to the success of its home-grown medium-term reform program (supported by the Fund's Stand-By Arrangement (SBA)), which will benefit the people of St. Kitts and Nevis and is fast becoming a model for other countries in the region. Since the SBA was approved in July 2011, we have been determined to advance our reform agenda and successfully implement our policies. This is reflected in having met our fiscal target and all other quantitative performance criteria and the structural benchmark for end-March 2012, as well as the structural benchmarks for endJune 2012. Our debt restructuring process is proceeding well and the domestic debt for land swap is under way. A shareholders' agreement has been signed, a management company responsible for selling the land assets incorporated, and lands have been registered and are in the process of being transferred. We welcome your continued strong support for these initiatives.

In the attached Memorandum of Economic and Financial Policies (MEFP) and the Technical Memorandum of Understanding (TMU), we present our plans to achieve the 2012 objectives of our program supported by the IMF. Based on the strength of these policies, and given our performance under the program and our continued commitment, we request the completion of the third program and financing assurances reviews, waiver of applicability for the end-June 2012 performance criteria, and the release of the fourth tranche of SDR 3.161 million. 
We are confident that the policies that we have committed to are adequate to achieve the objectives of our program. However, we need to remain vigilant to downside risks of lowerthan expected growth in the global economy and stand ready to take additional corrective actions that may become appropriate for this purpose as circumstances change. We will continue to consult with the Fund on the adoption of such actions in advance of necessary revision of policies contained in this letter and the attached Memorandum, in accordance with the IMF's policies.

The Government authorizes the IMF to make public the contents of this letter, the attached MEFP and TMU, and the Staff Report to clearly communicate our policies and to signal the seriousness of our commitment to the program to the people of St. Kitts and Nevis and to the international community.

Sincerely,

$/ \mathrm{s}$

Rt. Hon. Dr. Denzil Douglas

Prime Minister and Minister of Finance

St. Kitts and Nevis 


\section{ATTACHMENT I. Memorandum of ECONOMiC ANd Financial Policies}

1. St. Kitts and Nevis has made significant advances in implementing its home grown economic program supported by the IMF Stand By Arrangement (SBA). Our economic reform program continues to focus on putting public finances on a sustainable trajectory, finalizing a comprehensive debt restructuring to address the debt overhang, and further strengthening the financial system, in order to boost growth and employment. This Memorandum of Economic and Financial Policies (MEFP) updates these policies in the context of the third review under the SBA.

\section{Performance Under the Program}

2. We remain committed to successfully implementing our policies since the SBA was approved in July 2011 and have fulfilled our commitments under the program at end-March 2012 as detailed below. In addition, we expect to be on track to meet the program's end-June 2012 quantitative and structural reform targets. In this context, we request completion of the third program review and financing assurances review and request a waiver of applicability for the end-June 2012 performance criteria.

- Growth and inflation. Available indicators point to a softening of economic activity in January-March 2012. Construction continued to contract, by an estimated 20 to 25 percent (y/y), primarily on account of an under-execution of public investment in Nevis and sluggish FDI inflows. This dominated the effect of a relatively strong outturn in tourism, notably stay-over arrivals growing by 5.3 percent $(\mathrm{y} / \mathrm{y})$ relative to 0.4 percent (y/y) in January-March 2011. Inflation declined from 2.9 percent at endDecember 2011 to 1.9 percent (y/y) at end-March 2012, with a fading impact of the introduction of the VAT at end-2010 and moderating commodity prices. ${ }^{6}$

- $\quad$ External sector. Imports contracted relative to program expectations in January-March 2012, reflecting lower domestic demand. Combined with a good outturn for export and tourism receipts, the trade balance improved sufficiently to raise international reserves, net of IMF SBA resources, by EC\$25 million.

- $\quad$ Fiscal performance. All fiscal targets were met at end-March 2012, despite the continued challenging global environment and the much weaker-than-anticipated economic outturn for the first quarter of 2012. The overall fiscal balance at end-March 2012 reached a surplus of EC\$20 million, significantly above the adjusted program floor of EC\$-24 million. Similarly, the primary surplus of EC\$46 million also exceeded the program's indicative floor of EC\$7 million. Most gains came from

\footnotetext{
${ }^{6}$ Methodological improvements in the treatment of missing data in the CPI survey have resulted in an updated inflation time series.
} 
a sharp tightening in expenditure, particularly capital outlays, as total revenue was largely aligned with program expectations, buttressed by a strong performance of non tax revenue collected from the CIP. Tax revenue collection, particularly from VAT and customs duties, fell somewhat short of program expectations.

- Other performance criteria. The ceilings on central government budget expenditure arrears accumulation, the stock of external short-term debt, and the central government or guaranteed external arrears accumulation have all been met (Table 2).

- Debt restructuring. We have made progress in our comprehensive debt restructuring by:

> Initiating a debt/land swap with our domestic creditors. In conjunction with the shareholders' agreement signed on April 18, 2012, the management company responsible for selling the land assets was incorporated on April 5, 2012. About EC $\$ 900$ million of loans will be exchanged for land. In this context, an additional 600 acres of land have been registered and valued (structural benchmark for end-June). Negotiations are under way with the remaining domestic creditors.

> Concluding an agreement with our Paris Club creditors. On May 24, Paris Club creditor countries agreed on a flow rescheduling of 20 years with a 7 year grace period, a consolidation of 93 percent of current arrears, a full payment of moratorium interest during the consolidation period, and the inclusion of a goodwill clause pertaining to a future stock treatment. This agreement reduces by over 90 percent the debt service due to Paris Club creditors during the current Stand-By Arrangement program. We have contacted the United Kingdom and the United States bilaterally, with a view to agreeing to specific terms by end-October 2012. We have contacted our other bilateral creditors and discussions are ongoing.

Upon completion of the debt/land swap, we expect these operations, combined with our fiscal efforts, to reduce total public debt from 154.4 percent of GDP at end-2011 to just below 100 percent at end-2012, on the path to reach the ECCU target of 60 percent by end-2020.

- $\quad$ Financial sector. As of end-March 2012, the domestic financial sector remained adequately capitalized and liquid. Liquidity coverage of total deposits increased in the first quarter of 2012, as deposits - particularly time deposits - increased by more than credit to the private sector. The capital to risk-weighted asset ratio was maintained above 40 percent, far exceeding the prudential regional norm. The NPL ratio for locally incorporated banks declined from 6.8 percent at end-December 2011 to 6.4 percent at end-March 2012. Updated stress tests as of March 2012, completed 
by the Eastern Caribbean Central Bank (ECCB), confirm that the domestic banking sector is resilient to a range of shocks and would weather the full impact of the government debt restructuring. The ECCB's preliminary assessment of the impact of the debt/land swap is that the capital adequacy would remain above the prudential benchmark while the NPL ratio would increase due to the change in asset composition. There has been no request to date to access the Banking Sector Reserve Fund (BSRF) set up under the SBA.

- Trade Policies. We have actively engaged in trade agreements to promote trade, investment and employment in St. Kitts and Nevis. In addition to our existing bilateral non-reciprocal agreements with the Dominican Republic, Costa Rica, Cuba, Venezuela, and Colombia, we recently concluded a Partial Scope Agreement with Brazil and Guyana. The agreement, covering the electronic manufacturing sector, should be ratified by end-2012. Tariff reductions under the CARICOM Economic Partnership with the EU are scheduled for 2013. Implementation of the trade agreements is facilitated by the national trade policy committee-an inter-ministerial entity-which coordinates the harmonization of these agreements with domestic policies.

- $\quad$ Structural benchmarks. We met the structural benchmarks on submitting to Cabinet the proposal to rationalize the subsidy on LPG and the strategy for social safety net reform at end-March 2012. We have also completed the following structural benchmarks for end-June 2012: (i) we have established the land asset management company, and (ii) updated the registry for and, (iii) undertaken the valuation of, an additional 600 acres of land, (iv) we have established a medium-term expenditure framework with agreed fiscal targets, (v) we have submitted procurement legislation to Parliament and (vi) Cabinet has approved a comprehensive plan for civil service reform, covering human resource policy, reviewing the organization and structure of the civil service and addressing wage policy and payroll management.

\section{Policies During 2012}

3. A difficult first quarter and challenging global conditions suggest that economic activity will be flat in 2012. Economic growth is revised from 1 percent to zero in 2012. Growth in tourism is expected to moderate for the remainder of the year, due to uncertainty surrounding airlift capacity. However, construction activity should recover modestly, on the back of CIP approvals and stronger FDI inflows. Real GDP growth is projected to reach $13 / 4$ percent for 2013 and 4 percent over the medium term as tourism and construction continue to recover. Nonetheless, we remain mindful of the continued downside risks presented by the difficult global environment and are committed to implementing the necessary contingency measures to ensure that our fiscal strategy for 2012 remains fully aligned with the program. 


\section{A. Debt Restructuring}

4. Once the debt/land swap is completed, a swift pace of land sales is needed to adequately safeguard the financial position of the domestic creditors. We are proceeding with making the land asset management company fully functional, including in terms of operational guidelines, governance structure and staffing arrangements. In doing so, we intend to follow best practices related to transparency, accountability and the design of management incentives. We will submit to Parliament legislation for the transfer of land and plan to complete the transfer by end-September 2012. We count on the ECCB to continue to monitor the situation closely to ensure the health of the banking sector.

\section{B. Financial Sector}

5. We are committed, in conjunction with the ECCB, to continue to safeguard the stability of the financial sector. The ECCB's quarterly stress tests of the banking sector continue to be of great value to closely monitoring the banking sector. The BSRF will remain in place as an insurance policy. We remain committed to working with the CDB-ECCB-IMFWorld Bank Joint Financial Sector Task Force on addressing, as necessary, broader financial sector challenges in the region through a comprehensive regional approach. Finally, consistent with the IMF's safeguards policy requirement and current practice, we will continue to maintain all foreign exchange balances at the ECCB.

\section{Fiscal Policy}

6. We remain committed to the 2012 program target for the overall fiscal deficit of EC\$60 million, even if downside risks to the macroeconomic outlook are realized. Given increased uncertainty about achieving the annual tax revenue target, we will review the administrative practices with respect to the recording and offsetting of duties and taxes in order to strengthen the accounting procedures and minimize such occurrences. With the objective of bolstering tax revenue, in the short term, we will also seek technical assistance from our international partners to conduct an in-depth review of the concession regime on import duties and taxes, including the review of related legislation to determine the relevance and effectiveness of existing incentives. On the expenditure side, we intend to remove bottlenecks so that the implementation of the approved 2012 capital budget can proceed on a timely basis, within the confines of the 2012 budget, in order to provide additional impetus for economic growth. In the event that the revenue outturn exceeds program projections, we would see merit in further reducing the stock of budgetary arrears.

\section{Revenue}

7. We are pursuing further revenue administration reforms. Building on the institution of a single taxpayer identification number in 2011, we are strengthening verification controls by improving communication between the Customs and Excise Department (CED) and the Inland Revenue Department (IRD) and moving towards 
unification of the data bases. We have strengthened our control over large taxpayers, including the enforcement of assessments and have implemented the Tax Roll and Intelligence Unit. We are developing risk-based audit methods for the corporate income tax and customs duties and expect over the medium-term to commence joint audits by the CED and the IRD. We have also strengthened accountability of the IRD by implementing performance indicators in each of its sections and systematized the cross-checks between the Housing and Social Development Levy and social security contributions for all large taxpayers. We have drafted a new Customs Law, which harmonizes the systems and procedures of the CED and clarifies guidelines on investigation methods. While 90 percent of Customs declarations are already made electronically, we aim to extend the regime of electronic registry to all taxpayers registered as businesses and are harmonizing the International Standard Industrial Classification (ISIC) codes.

8. We are broadening the tax base. The Income Tax Act was amended in April 2012 to include in-kind payments in the tax base, which is expected to generate approximately EC $\$ 2$ million ( 0.1 percent of GDP) in additional revenue on an annual basis and limit to one cost center per business the eligible threshold of deductible remuneration paid to an employee. We also intend to update the model for calculating the tax obligations of insurance companies. We continue to monitor the revenue cost of customs duties and tax exemptions, the former estimated at EC\$24 million (1.2 percent of GDP) in January-March 2012, with the intention of completing their review and streamlining them over the medium-term.

\section{Expenditure}

9. We will continue to tightly control current expenditure while accelerating priority capital spending. We will maintain the freeze on the wage bill and limit the growth of expenditure on goods and services. As an additional step towards improving the efficiency of government operations we intend to close the Supply Office in St. Kitts by end August 2012 and are assessing options for a more cost-effective management of price controls for staple food items.

\section{Fiscal structural reforms}

10. To increase fiscal space for priority spending, following our recent advances in public expenditure management, we are improving the efficiency of public outlays by:

- Rationalizing social protection programs. We have initiated the process of consolidating four of the existing cash transfer programs and improving their targeting by shifting the recipients from individuals to households. We also aim to limit the time duration of these benefits per beneficiary by strengthening support for its eventual exit from the program. With technical assistance, we will focus on the establishment of the legislative framework to support the safety net program and ascertain a means test (SB for end September 2013) to determine eligibility to the 
program as well as a system to facilitate graduation from the program. Once this new system of delivery of social protection programs is in place, we will examine the scope for extending it to subsidies on LPG and basic food staples, in order to improve their targeting to the neediest.

- Containing contingent liabilities from public enterprises. The Finance Administration Act requires that overdrafts of public enterprises that are guaranteed by the government, currently amounting to EC\$ 2.5 million ( 0.1 percent of GDP) be given in accordance with the provisions of an Act authorizing the guarantee or by resolution of the National Assembly. To enhance the government's oversight of public enterprises and their compliance with financial reporting requirements, we plan to formally recognize the authority of the Government Entities Oversight Board to engage auditors for investigative purposes and strengthen its enforcement capacity by including a provision to that effect in the Finance Administration Act (SB for end-March 2013). We have clarified the government's financial relationship with the St. Kitts Electricity Company (SKELEC) and intend to settle mutual claims of cross-arrears that have accumulated since its corporatization in August 2011 by August 2012. As SKELEC continues implementing its program of revenue recovery and adjusting electricity tariffs in line with international fuel prices, we expect that it will generate sufficient resources to cover its debt servicing obligations over the medium term.

- Enhancing the Public Sector Investment Program. We have formulated a Public Financial Management (PFM) Action Plan for 2012-15 in May, 2012. In the context of the Medium-Term Expenditure Framework, we are refining the three-year fiscal forecast to be included in the 2013 Budget. Inter alia, this will allow us to strengthen the monitoring of capital projects and their recurrent cost implications in light of sectoral strategies.

\section{We continue to strengthen our cash management system to avoid the}

accumulation of arrears. We are improving our systems to identify payment deadlines based on terms of sales, limiting departments' access to spending lines once they exceed their limit for incomplete purchase orders, and eliminating inactive donor accounts.

\section{In the context of the OECS Pension Commission, we are exploring a number of} pension reforms that would help ensure long-term sustainability. One of the important milestones is the tenth actuarial review of the Social Security fund. Due to administrative delays, we now envisage that this review will be completed by end-December 2012, resulting in the rephasing of the relevant structural benchmark. After consulting with stakeholders, policy options under consideration include increasing the retirement age, reducing the accrual rate and modifying the pensionable base. We anticipate having a firm proposal on these reforms developed by end-June 2013 (SB). 
13. Progress has been made in improving fiscal transparency. We intend to commence quarterly publication of reports on fiscal operations by end-2012 and gross financing needs starting in June 2013. The audited financial statements of the Sugar Industry Diversification Foundation (SIDF), a private foundation, have been published for the years 2007-2010 and the publication of the accounts for 2011 should take place later in 2012.

Table 1. St. Kitts and Nevis: Schedule of Review and Purchases

\begin{tabular}{|c|c|c|c|}
\hline \multirow[b]{2}{*}{ Availability date } & \multicolumn{2}{|c|}{ Amount of Purchase } & \multirow[b]{2}{*}{ Conditions } \\
\hline & Millions of SDR & Percent of Quota & \\
\hline July 27, 2011 & 22.150 & 248.9 & Approval of arrangement \\
\hline January 25, 2012 & 11.470 & 128.9 & First review and end-September 2011 performance criteria \\
\hline May 21, 2012 & 3.161 & 35.5 & Second review and end-December 2011 performance criteria \\
\hline May 25, 2012 & 3.161 & 35.5 & Third review and end-March 2012 performance criteria \\
\hline August 15, 2012 & 3.161 & 35.5 & Fourth review and end-June 2012 performance criteria \\
\hline November 15, 2012 & 3.161 & 35.5 & Fifth review and end-September 2012 performance criteria \\
\hline February 15, 2013 & 1.105 & 12.4 & Sixth review and end-December 2012 performance criteria \\
\hline May 15,2013 & 1.105 & 12.4 & Seventh review and end-March 2013 performance criteria \\
\hline August 15, 2013 & 1.105 & 12.4 & Eight review and end-June 2013 performance criteria \\
\hline November 15, 2013 & 1.105 & 12.4 & Nineth review and end-September 2013 performance criteria \\
\hline February 15, 2014 & 0.913 & 10.3 & Tenth review and end-December 2013 performance criteria \\
\hline May 15, 2014 & 0.913 & 10.3 & Eleventh review and end-March 2014 performance criteria \\
\hline Total & 52.510 & 590.0 & \\
\hline
\end{tabular}

Table 2. St. Kitts and Nevis: Quantitative Performance Criteria and Indicative Targets

(In EC\$ millions)

\begin{tabular}{|c|c|c|c|c|c|c|c|c|}
\hline & \multicolumn{3}{|c|}{ End-Dec 2011} & \multicolumn{5}{|c|}{ End-Mar. 2012} \\
\hline & Prog. & Adjusted & Actual & Prog. & Adjusted & Actual & Difference & Status \\
\hline \multicolumn{9}{|l|}{ Performance Criteria: } \\
\hline Central government overall balance including grants (floor) $1 / 2$ / & -60 & -35 & 43 & -24 & -24 & 20 & 43 & met \\
\hline Stock of central government budget expenditure arrears accumulation (ceiling) $3 /$ & 0 & 0 & -16 & 0 & 0 & -27 & -27 & met \\
\hline Stock of external short term debt (ceiling) & 0 & 0 & 0 & 0 & 0 & 0 & 0 & met \\
\hline Central government or guaranteed external arrears accumulation (ceiling) 4/ & 0 & 0 & 0 & 0 & 0 & 0 & 0 & met \\
\hline \multicolumn{9}{|l|}{ Indicative Target: } \\
\hline Central government primary balance (floor) $1 / 2 /$ & 76 & 101 & 169 & 7 & 7 & 46 & 39 & met \\
\hline
\end{tabular}

$1 /$ Cumulative within each calendar year.

2/ See the TMU for a description of adjustors.

3 Including the estimated stock of expenditure payable on electricity

4 / To be monitored on a continuous basis. 
Table 3. St. Kitts and Nevis: Quantitative Performance Criteria for 2012 and Indicative Target for 2013 (In millions of Eastern Caribbean dollars)

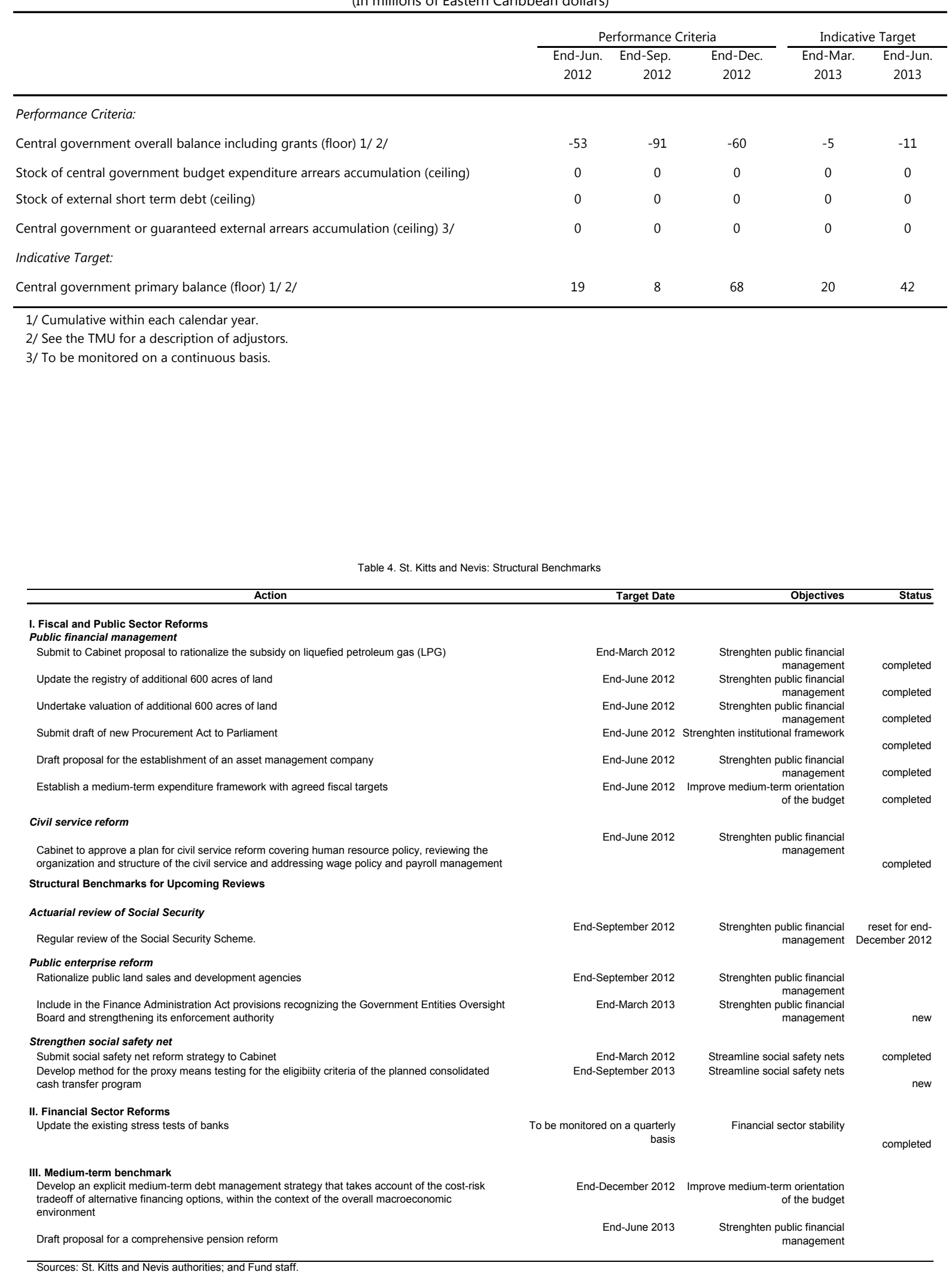




\section{ATtACHMENT II. TECHNICAL MEMORANDUM OF UNDERSTANDING}

1. St. Kitts and Nevis' performance under the Stand-By Arrangement (SBA) will be assessed on the basis of the quantitative performance criteria and indicative targets, as well as the structural benchmarks. This Technical Memorandum of Understanding (TMU) defines the variables set out in Table 2 of the Memorandum of Economic and Financial Policies (MEFP). It also lays down the reporting requirements to adequately monitor the program.

2. For the purposes of the program, the exchange rate of the East Caribbean dollar (EC\$) to the U.S. dollar is set at EC $\$ 2.70=$ US\$1 and the exchange rate of the Euro to the U.S. dollar is set at EUR1 $=$ US\$1.3. Foreign currency accounts denominated in currencies other than the U.S. dollar and the Euro, excluding SDRs, will be first valued in the U.S. dollar at actual end-of-period exchange rates used by the ECCB to calculate the official exchange rates. SDR-denominated accounts will be valued at the program exchange rate of U.S. dollar 1.6 per SDR.

\section{Coverage}

3. For the purpose of the program, central government will cover all items included in the government budgets of the Federation (both St. Kitts and Nevis).

4. The nonfinancial public sector is defined as the total central government and nonfinancial public enterprises. Public enterprises consist of the Development Bank of St. Kitts and Nevis, Financial Services Regulatory Commission, Frigate Bay Development Corporation, La Vallee Greens Ltd, National Housing Corporation, Nevis Air and Sea Port Authority, Nevis Cultural Development Foundation, Nevis Electricity Corporation, Nevis Housing and Land Development Corporation, Nevis Solid Waste Management Authority, Nevis Tourism Authority, St. Christopher and Nevis Solid Waste Management Corporation, St. Christopher Tourism Authority, St. Kitts Urban Development Corporation, St. Christopher Air and Sea Ports Authority, WhiteGate Development Corporation, and ZIZ Broadcasting Corporation.

5. External debt is defined as all debt owed to creditors residing outside of St. Kitts and Nevis, while domestic debt covers all debt owed to residents of St. Kitts and Nevis. The latter covers all T-bills, including those held by creditors residing outside of St. Kitts and Nevis, and the bond issued at the Regional Government Securities Market (RGSM).

\section{Quantitative Performance Criteria}

\section{A. Central Government's Overall Deficit (PC)}

6. The central government overall balance will cover all of its revenue, grants, expenditure, and transfers. Revenues will exclude any proceeds from the sale of public assets 
such as land, which will be considered as financing below the line. Expenditures will exclude clearance of arrears, which will be considered as financing below the line.

7. The central government's overall balance will be measured from the financing side as the sum of the net domestic financing, net external financing, plus proceeds from the sale of public assets, minus clearance of arrears.

8. Net domestic financing of the central government is defined as the sum of:

- $\quad$ net domestic bank financing as measured by the change in the domestic banking system credit to the central government net of deposits, as reported by the consolidated balance sheet of the monetary authorities and commercial banks, including special tranches from the ECCB;

- $\quad$ net nonbank financing as measured by the net changes in holdings of government securities by nonbanks, and net borrowing from nonbank institutions;

- the changes in the stock of domestic arrears of the central government defined as net changes in unpaid checks issued, unprocessed claims, pending invoices, plus accrued interest payments, and other forms of expenditures recorded above the line but not paid;

- $\quad$ gross receipts from divestment defined as proceeds received from any privatization, divestment, and sale of asset (land); and

- $\quad$ any exceptional financing, including rescheduled principal and interest.

9. Net external financing of the central government is defined as the sum of:

- disbursements of project and non-project loans, including securitization;

- $\quad$ proceeds from bonds issued abroad (with an original maturity of one year or greater);

- net changes in short-term external debt (with an original maturity of less than one year), excluding exceptional financing;

- $\quad$ net changes in cash deposits held outside the domestic banking system;

- $\quad$ any changes in arrears on external interest payments and other forms of external expenditures recorded above the line but not paid;

- $\quad$ any exceptional financing, including rescheduled principal and interest; 
less:

- $\quad$ payments of principal on current maturities for bonds and loans on a due basis, including any prepayment of external debt.

10. The floor on the overall balance of the central government will be adjusted as follows:

- downward (i.e., a larger overall deficit target would apply) to the extent that budgetary grants fall short of the programmed amounts by less than EC\$3 million.

- upward to the extent that budgetary grants exceed the annual amounts specified in the program.

- downward by the cumulative amount of up to EC\$15 million spent on bank recapitalization and support to the British American Insurance Companies or CLICO as part of a regional solution - any amounts spent in excess of this programmed contingency will need to be funded within the program limit on the overall deficit.

- upward to the extent that clearance of arrears fall short of the amounts specified.

- upward to the extent of exceptional financing achieved through debt restructuring.

Table 1. Programmed Disbursements of Budgetary Grants in 2012 (in EC\$ millions)

\begin{tabular}{|c|c|c|c|c|c|}
\hline & Quarters & $T$ & II & III & IV \\
\hline Grants & & 0.0 & 0.0 & 0.0 & 27.4 \\
\hline
\end{tabular}

Sources: St. Kitts and Nevis authorities; and Fund staff estimates. Note: Values presented are cumulative and Euro $1=$ US $\$ 1.3$.

\section{B. Stock of Central Government Short-Term External Debt (PC)}

11. The limit on short-term external debt applies to debt owed or guaranteed by the central government of St. Kitts and Nevis, with an original maturity of up to and including one year. Excluded from the limit are any rescheduling operations (including the deferral of interest on commercial debt) and normal import-related credits. Normal import credit is understood to be a self-liquidating operation where the proceeds from sales of imports are 
used to retire the debt. Debt falling within the limit shall be valued in U.S. dollars at the time of the contract or guarantee becomes effective.

\section{External Arrears of the Public Sector (PC)}

12. The non-accumulation of arrears to external creditors will be a continuous performance criterion under the program. This performance criterion applies to arrears accumulated related to debt contracted or guaranteed by central government. External payment arrears consist of external debt service obligations (principal and interest) falling due after December 31, 2010 that have not been paid at the time due, taking into account the grace periods specified in contractual agreements. Arrears resulting from nonpayment of debt service for which a clearance framework has been agreed or a rescheduling agreement is being sought are excluded from this definition.

\section{Budget Expenditure Arrears (PC)}

13. A ceiling is set on central government budget expenditure arrears, equal to the stock of such arrears as at December 31, 2010 (Table 2). The ceiling applies to the increase in the sum of: (1) any invoice that has been received by a spending agency from a supplier of goods, services, and capital goods delivered and verified, and for which payment has not been made within the contractually agreed period, or in the absence of a grace period, within 60 days; and (2) unpaid wages, pensions, or transfers, pending for longer than 60 days to domestic or foreign residents, irrespective of the currency denomination of the debt. Interest and amortization arrears on domestic debt resulting from nonpayment of debt service for which a clearance framework has been agreed or a rescheduling agreement is being sought are excluded from this ceiling. For ease of monitoring, all debt issued on the Regional Government Securities Market (RGSM), irrespective of who holds it, will be regarded as domestic debt.

Table 2. Stock of Budget Expenditure Arrears at end-December, 2010 (in EC\$ millions)

\begin{tabular}{lr}
\hline Stock of arrears 1/ & 133 \\
Unpaid check issued & $\ldots$ \\
Unprocessed invoices & $\ldots$ \\
Pending invoices & $\ldots$ \\
Interest and amortization arrears on domestic debt & 0 \\
Total & 133 \\
\hline
\end{tabular}

Source: St. Kitts and Nevis authorities.

$1 /$ Including the stock of arrears related to fuel purchases audited by international auditors. 


\section{Indicative Target on the Primary Balance of the Central Government}

14. The central government's primary balance is defined as revenue and grants minus non-interest expenditures. As in the definition of the overall balance, revenue will exclude any proceeds from the sale of public assets. Net lending is a non-interest expenditure item (negative net lending is a revenue item). Interest expenditures include interest payments on outstanding arrears, as defined above in sections IIC and IID (at their contractual rates) converted to a cash basis.

15. The floor on the primary balance of the central government will be monitored from the financing side as the sum of the net domestic financing, net external financing, proceeds from the sale of public assets, plus domestic and external interest payments on a due basis.

16. The floor on the primary balance of the central government will be adjusted as follows:

- downward (i.e., a smaller primary surplus target would apply) to the extent that budgetary grants fall short of the programmed amounts by less than EC\$3 million.

- upward to the extent that budgetary grants exceed the annual amounts specified in the program.

- downward by the cumulative amount of up to EC $\$ 15$ million spent on bank recapitalization and support to the British American Insurance Companies or CLICO as part of a regional solution.

- upward to the extent of exceptional financing achieved through debt restructuring.

\section{DATA AND INFORMATION}

17. To enable monitoring of performance relative to the above quantitative performance criteria and indicative targets, the St. Kitts and Nevis authorities will provide Fund staff with the following specific data and information within 8 weeks after the end of each month.

\section{Fiscal sector}

- Central government budgetary accounts.

- $\quad$ Capital expenditure. 
- Total monthly disbursements and grants receipts, disaggregated into: (a) budgetary support (by type - either loans, external "bonds" and/or other securities); (b) project loans; (c) budgetary grants; and (d) project grants.

- $\quad$ Central government domestic debt data (St. Kitts and Nevis).

- $\quad$ Stock of domestic arrears, including unpaid checks issued, stock of unprocessed claims due and invoices pending; interest and amortization on domestic debt.

- $\quad$ Stock of external arrears by creditor.

- Detailed monthly external debt report from the Debt Unit in the Ministry of Finance, showing fiscal year-to-date disbursements, amortization, interest payments and outstanding stocks, for the central government and public enterprises.

- $\quad$ Copies of loan agreements for any new loans contracted, including financing involving the issue of government paper, and of any renegotiated agreements on existing loans.

\section{Financial sector}

- Monetary survey for St. Kitts and Nevis as prepared by the Eastern Caribbean Central Bank.

\section{Real sector}

- $\quad$ Consumer price index.

18. Reporting on a quarterly basis will include the following:

\section{Fiscal}

- A detailed overview of capital expenditures on a project by project basis and the composition of financing.

- $\quad$ Financial position of the public enterprises (as listed in paragraph 4).

\section{Real sector}

- Economic indicators under the real sector.

\section{External sector}

- Economic indicators under the external sector. 
19. Reporting on an annual basis will include the following:

External and real sectors

- $\quad$ GDP and its components.

- $\quad$ Balance of payments accounts.

20. Other reporting will include:

- $\quad$ Reports of legislative changes pertaining to economic matters.

- Notification of any establishment of new public enterprises.

- All disbursements and outstanding balances from the use of the Banking Sector Reserve Fund on a weekly basis. 
August 3, 2012

\section{IMF Executive Board Completes Third Review Under Stand-by Arrangement with St. Kitts and Nevis and Disburses US\$4.76 Million}

The Executive Board of the International Monetary Fund (IMF) today completed the third review of St. Kitts and Nevis' economic performance under a program supported by a 36-month Stand-by Arrangement (SBA). The completion of the review allows the immediate disbursement of an amount equivalent to SDR 3.16 million (about US\$ 4.76 million), bringing total disbursements under the arrangement to SDR 39.94 million (about US\$ 60.21 million).

The Executive Board also approved a request for waivers of applicability for the end-June 2012 performance criteria. These waivers were necessary because the Executive Board meeting was scheduled to take place after end-June but prior to the availability of data to assess the relevant PCs.

The SBA was approved on July 27, 2011 (see Press Release No. 11/295), for an amount equivalent to SDR 52.51 million (about US\$79.15 million), or 590 percent of St. Kitts and Nevis' IMF quota.

Following the Executive Board's discussion, Min Zhu, Deputy Managing Director and Acting Chair, issued the following statement:

"While the outlook for the St. Kitts and Nevis economy is for a moderate recovery, weaker domestic activity and the persisting difficult global environment pose challenges. The authorities are continuing to successfully implement their Fund-supported program and remain committed to the sound macroeconomic policies and sustaining the pace of structural reforms.

"The authorities have made further progress on restructuring the public debt and have reached an agreement with Paris Club creditors. Similar negotiations with other bilateral creditors will be necessary to secure debt sustainability. The debt-land swap has also advanced. Key priority now is the swift operational implementation of the Special Purpose Vehicles (SPVs). It will be important to align the governance structure and staffing of these 
SPVs with best international practices to ensure transparency and accountability. Successful completion of debt restructuring will yield debt service savings, which will help shore up the fiscal position.

"Continued successful program implementation and the achievement of medium-term fiscal targets will depend on a sound macroeconomic framework, including further broadening the tax base, strengthening revenue administration, and improving the efficiency of public spending. Reforms in public financial management will help enhance the quality of adjustment and provide the fiscal space needed to accelerate growth-enhancing expenditures, particularly public infrastructure investment.

"The financial sector remains healthy and adequately capitalized. Continued close monitoring and collaboration with the Eastern Caribbean Central Bank to address any repercussion of the debt-land swap and debt rescheduling on banks' liquidity and profitability should be an important priority." 